\title{
Biochemical insight into novel Rab-GEF activity of the
}

\section{mammalian TRAPPIII complex}

5 Noah J Harris ${ }^{1}$, Meredith L Jenkins ${ }^{1}$, Udit Dalwadi², Kaelin D Fleming ${ }^{1}$, Sung-Eun-Nam², 


\section{Abstract}

Transport Protein Particle complexes (TRAPP) are evolutionarily conserved

24 regulators of membrane trafficking, with this mediated by their guanine nucleotide

25 exchange factor (GEF) activity towards Rab GTPases. In metazoans evidence suggests

26 that two different TRAPP complexes exist, TRAPPII and TRAPPIII. These two complexes

27 share a common core of subunits, with complex specific subunits (TRAPPC9 and

28 TRAPPC10 in TRAPPII and TRAPPC8, TRAPPC11, TRAPPC12, TRAPPC13 in

29 TRAPPIII). TRAPPII and TRAPPIII have distinct specificity for GEF activity towards Rabs,

30 with TRAPPIII acting on Rab1, and TRAPPII acting on Rab1 and Rab11. The molecular

31 basis for how these complex specific subunits alter GEF activity towards Rab GTPases

32 is unknown. Here we have used a combination of biochemical assays, hydrogen

33 deuterium exchange mass spectrometry (HDX-MS) and electron microscopy to examine

34 the regulation of TRAPPII and TRAPPIIII complexes in solution and on membranes. GEF

35 assays revealed that the TRAPPIII has GEF activity against Rab1 and Rab43, with no

36 detectable activity against the other 18 Rabs tested. The TRAPPIII complex had

37 significant differences in protein dynamics at the Rab binding site compared to TRAPPII,

38 potentially indicating an important role of accessory subunits in altering the active site of

39 TRAPP complexes. Both the TRAPPII and TRAPPIII complexes had enhanced GEF

40 activity on lipid membranes, with HDX-MS revealing numerous conformational changes

41 that accompany membrane association. HDX-MS also identified a membrane binding site

42 in TRAPPC8. Collectively, our results provide insight into the functions of TRAPP

43 complexes and how they can achieve Rab specificity. 
Introduction

Membrane trafficking is an essential process in all eukaryotic cells and requires

46 tightly coordinated transport of cellular material to distinct intracellular organelles.

47 Numerous different proteins are involved in regulating this pathway but one of the most

48 important protein families involved are Rab GTPases. Rabs act as molecular switches

49 that cycle between GTP-bound active and GDP-bound inactive states. Rabs recruit

50 downstream effector molecules depending on their nucleotide binding state, including

51 molecular motors, and tethers which control membrane trafficking events. The activation

52 of Rabs is catalyzed by Guanine nucleotide exchange factors (GEFs) [1-3] which mediate

53 the exchange of GDP for GTP. Defining how Rabs are targeted by GEFs is important in

54 understanding their function in membrane trafficking. The Transport Protein Particle

55 (TRAPP) complexes are evolutionarily conserved in all eukaryotic cells, and are potent

56 Rab GEFs playing important roles in secretion, autophagy, and Golgi trafficking [4-9].

Metazoans are proposed to form two different TRAPP complexes: TRAPPII and

TRAPPIII. TRAPPII can activate Rab1, but it has been proposed that its main role is to

59 activate Rab11, therefore playing key roles in secretion from the Golgi [10-13]. TRAPPIII

60 does not have activity against Rab11, and instead is proposed to primarily mediate

61 activation of Rab1, an important regulator in ER-Golgi, intra-Golgi trafficking and

62 autophagy $[11,14-16]$. The mammalian TRAPPII complex has additional activity on

63 Rab19 and Rab43 [10]. Rab19 and Rab43 are both Golgi-localised Rabs, with Rab43

64 being involved in mediating GPCR trafficking [17]. Defining the molecular mechanisms 
65 that mediate GEF specificity of mammalian TRAPP complexes will be critical in 66 understanding their roles in membrane trafficking.

67 TRAPPI, TRAPPII and TRAPPIII all share seven conserved subunits that make up 68 the TRAPP "core" (TRAPPC1, TRAPPC2, TRAPPC2L, TRAPPC3A/B, TRAPPC4, 69 TRAPPC5, TRAPPC6A/B) [18]. Mammalian TRAPPII is composed of the core and two 70 additional complex specific subunits (TRAPPC9, TRAPPC10) with mammalian TRAPPIII 71 composed of the core and four additional complex specific subunits (TRAPPC8, 72 TRAPPC11, TRAPPC12, TRAPPC13) $[11,19,20]$. The importance of TRAPPIII as a Rab1

73 GEF is highlighted by TRAPPC8 and TRAPPC11 being essential for cell survival and

74 Rab1 activation [11,21]. Highlighting the critical role of TRAPP complexes in human 75 disease is that mutations or deletions in TRAPP specific subunits have been found to be 76 involved in several neurodevelopmental disorders collectively known as 77 “TRAPPopathies" [5,6,9].

Structural studies using X-ray crystallography and electron microscopy have revealed the architecture of the conserved core of the TRAPP complexes and how they

80 associate with Rab GTPases (Fig. 1A) [18,22]. The structure of the yeast TRAPP core

81 complex bound to Ypt1 (Rab1 homolog) revealed the Rab binding interface which is 82 composed of TRAPPC1, TRAPPC3, and TRAPPC4 [18,22]. The cryo-electron

83 microscopy (cryo-EM) structure of the yeast TRAPPIII complex revealed the interactions

84 of the core with TRAPPC8, with an additional interaction of TRAPPC5 with the hyper-

85 variable tail (HVT) of Ypt1 (Rab1 homolog) [23]. The cryo-EM structure of the Drosophila

86 TRAPPIII complex bound to Rab1 shows how the additional TRAPPIII complex specific 
87 subunits are arranged in relation to the core, with a novel interaction between TRAPPC8

88 and Rab1 [24]. Despite these insights into the assembly of TRAPPIII complexes, it is still

89 not understood how the TRAPPIII complex specific subunits change the way the

90 conserved subunits interact with Rab substrates, and how substrate selectivity is

91 controlled.

92 Here we have carried out biochemical and biophysical analysis of the mammalian

93 TRAPPIII complex using a combination of in-vitro GEF assays, electron microscopy, and

94 hydrogen deuterium exchange mass spectrometry (HDX-MS). We have purified both

95 mammalian TRAPPII (composed of TRAPPC1, TRAPPC2, TRAPPC2L, TRAPPC3,

96 TRAPPC4, TRAPPC5, TRAPPC6A, TRAPPC9, TRAPPC10) and TRAPPIII (composed

97 of TRAPPC1, TRAPPC2, TRAPPC2L, TRAPPC3, TRAPPC4, TRAPPC5, TRAPPC6A,

98 TRAPPC8, TRAPPC11, TRAPPC12, TRAPPC13). Single-particle electron microscopy

99 analysis of the purified TRAPPIII revealed an overall architecture resembling that of

100 TRAPPIII isolated from Drosophila. We characterised TRAPPIII GEF activity against 20

101 different Rab GTPases both in solution and on membranes. We found TRAPPIII mediated

102 GEF activity for Rab1 and Rab43, but no activity towards other any other Rab GTPases

103 tested. HDX-MS comparing the TRAPPII and TRAPPIII complexes showed extensive

104 differences at the Rab binding site, revealing a potential role of complex specific subunits

105 in reshaping the GEF catalytic site. GEF activity of both TRAPPII and TRAPPIII was

106 enhanced on membranes, with HDX-MS revealing extensive conformational changes

107 upon membrane binding and identifying a conserved membrane binding site in the

108 TRAPPIII specific subunit TRAPPC8. Overall, this work provides unique insight into the 
109 architecture and dynamics of TRAPP complexes, and the mechanisms by which their

110 GEF activity is regulated.

112 Results

113 Purification and architecture of the mammalian TRAPPIII complex

114 We recombinantly purified TRAPPII and TRAPPIII using a similar approach to our

115 previous work on TRAPPII [10]. TRAPPII and TRAPPIII complexes were generated using

116 the biGBac multi-promoter system [25] in Sf9 insect cells and protein purification was

117 carried out using HisTrap and StrepTrap affinity columns followed by gel filtration (Fig.

118 1B). The details outlining the specific plasmids and TRAPP subunit boundaries used can

119 be found in Table S1. TRAPPIII eluted at a size consistent with one copy of all subunits

120 (exception being two copies of TRAPPC3) on size exclusion chromatography. Tandem

121 mass spectrometry (MS/MS) analysis of the purified TRAPPII and TRAPPIII complexes

122 identified peptides covering all expressed subunits.

123 To investigate the architecture of the mammalian TRAPPIII complex we subjected

124 purified mammalian TRAPPIII to negative stain single particle electron microscopy (EM)

125 analysis (Fig. 1C-D, Fig. S1). Raw images revealed triangular-shaped particles similar to

126 Drosophila TRAPPIII [24] but distinct from the smaller-sized yeast TRAPPIII [23]. Two-

127 dimensional (2D) analysis and 3D reconstruction revealed mammalian TRAPPIII is

128 composed of an elongated rod-like region reminiscent of the TRAPP core (TRAPPC1,

129 TRAPPC2, TRAPPC3A/B, TRAPPC4, TRAPPC5, TRAPPC6A), two "arms" capping the

130 ends of the putative TRAPP core, and a peripheral region extending from the core (Fig. 
131 1D). The ultrastructure of mammalian TRAPPIII is consistent with the cryo-EM structure

132 of Drosophila TRAPPIII which identified a triangular-shaped complex with a similar rod-

133 like TRAPP core that contains TRAPPC8 and TRAPPC11 "arms" on either end of the

134 core with a peripheral TRAPPC12/C13 region extending from this core region. This 135 suggests a highly conserved architecture between TRAPPIII complexes in metazoans.

136
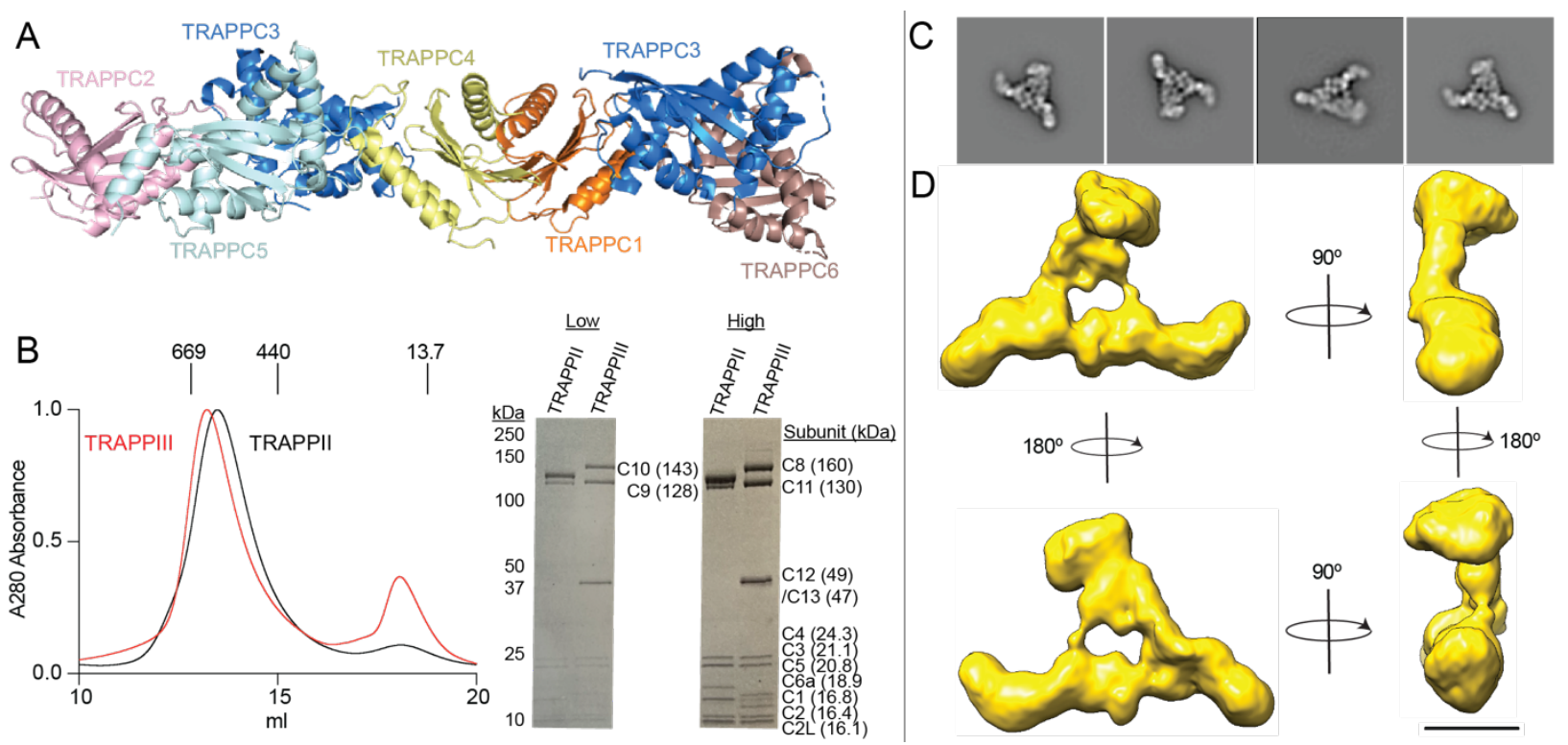

137 Figure1. Purification and Architecture of the mammalian TRAPPIII complex

138 A. Model of the mammalian TRAPP conserved subunits. The model was generated

139 through a combination of the following structures (PDB: 2J3T, 2J3W, and 3CUE) Phyre2

140 was used to generate structures of mammalian TRAPP subunits with no solved crystal

141 structure [26].

142 B. left: Size Exclusion Chromatography (SEC) trace of TRAPPII and TRAPPIII on a

143 Superose 6 gel filtration column with molecular weight markers indicated in kDa.

144 Absorbance is normalized to max absorbance. Right: SDS-PAGE gel of purified 
145 mammalian TRAPPII and TRAPPIII complex. Protein composition is shown on the right.

146 High and low labels refer to protein amount loaded (high=3.6 $\mu \mathrm{g}$ and low $=1.4 \mu \mathrm{g}$ ).

147 C. Representative 2D negative stain electron microscopy class averages of the TRAPPIII

148 complex. Box edge length is $670 \AA$.

149 D. 3D EM reconstruction of TRAPPIII with different orientations of the complex. Scale bar 150 represents $100 \AA$.

\section{Determination of mammalian TRAPPIII Rab Specificity}

To examine the specificity of the GEF activity of the mammalian TRAPPIII complex

we tested 20 different Rab GTPases. We focused on Rab GTPases that are evolutionarily

155 similar to Rab1 and Rab11, to identify possibly overlooked Rabs. GEF assays were

156 carried out using Rabs preloaded with the fluorescent GDP analog 3-(N-methyl-

157 anthraniloyl)-2-deoxy-GDP (Mant-GDP) and nucleotide exchange was determined as a

158 function of TRAPP concentration. Rab GTPases were designed with a C-terminal his tag

159 which allowed for GEF activity to be measured in the presence of NiNTA containing 160 synthetic membranes.

161 In solution, the TRAPPIII complex had GEF activity on Rab1 with a catalytic

162 efficiency of $\sim 1.7 \times 10^{3} \mathrm{M}^{-1} \mathrm{~S}^{-1}$ which is similar to the catalytic efficiency that we previously

163 determined for TRAPPII on Rab1 $\left(2.9 \times 10^{3} \mathrm{M}^{-1} \mathrm{~S}^{-1}\right)$ and consistent with TRAPPIII's role as

164 a Rab1 GEF [11,14] (Fig. 2C). Similar to TRAPPII, we found TRAPPIII mediated activity 165 towards Rab43. TRAPPIII showed increased catalytic efficiency for Rab43 compared to

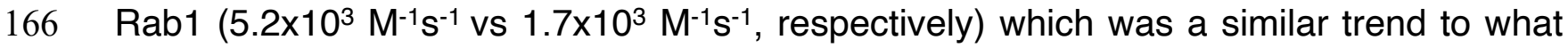


167 was observed with the mammalian TRAPPII complex (Fig. 2C) [10]. There was no

168 detectable TRAPPIII mediated GEF activity for any other Rab GTPase tested including

169 Rab11a, Rab11b, or Rab19 which are substrates for mammalian TRAPPII (Fig. 2D). This

170 is consistent with TRAPPIII having GEF activity for Rab1 but not Rab11 in both

171 metazoans and yeast [11,27]. The lack of GEF activity for TRAPPIII with Rab19 was

172 striking because Rab43 and Rab19 are very evolutionarily similar to each other, only

173 diverging in vertebrata with TRAPPII being able to activate both Rab19 and Rab43. A

174 conservational alignment of these GTPases is shown in supplemental figure 2.

175 Collectively, our in-vitro analysis of TRAPPIII shows that TRAPPIII is a specific GEF for

176 Rab1a and Rab43 in solution and reveals insight into an unexpected difference in GEF

177 activity between TRAPPII and TRAPPIII towards Rab19. There is no clear sequence

178 relationship explaining the selectivity of why TRAPPII, but not TRAPPIII, is active on

179 Rab19/Rab11 (Fig. S2), presenting a need for further high resolution structural studies to

180 help define this. 
A

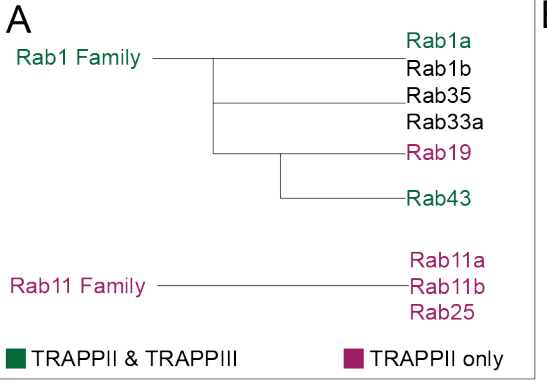

C
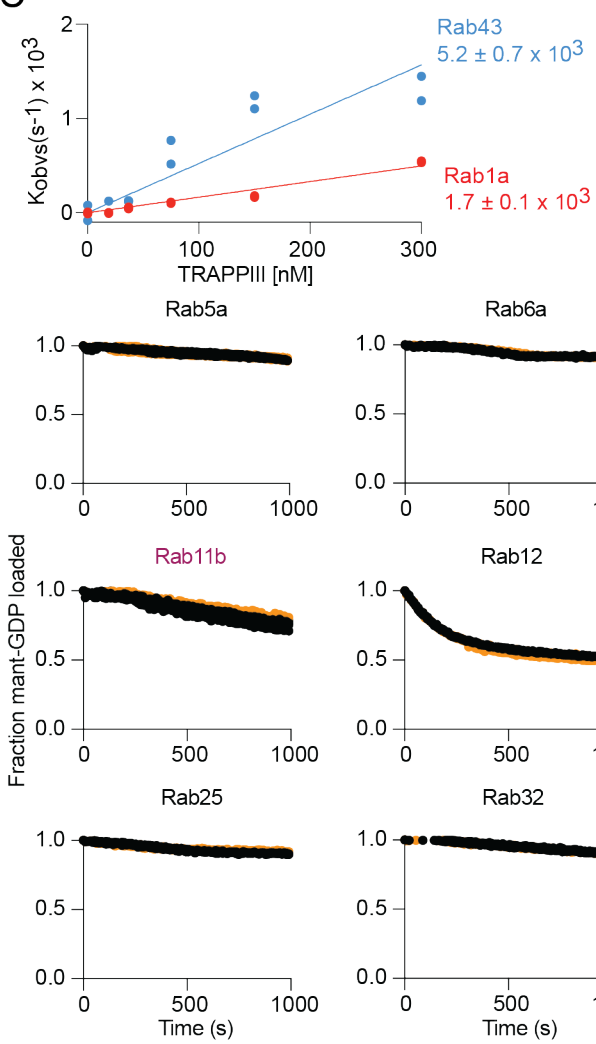

$B$
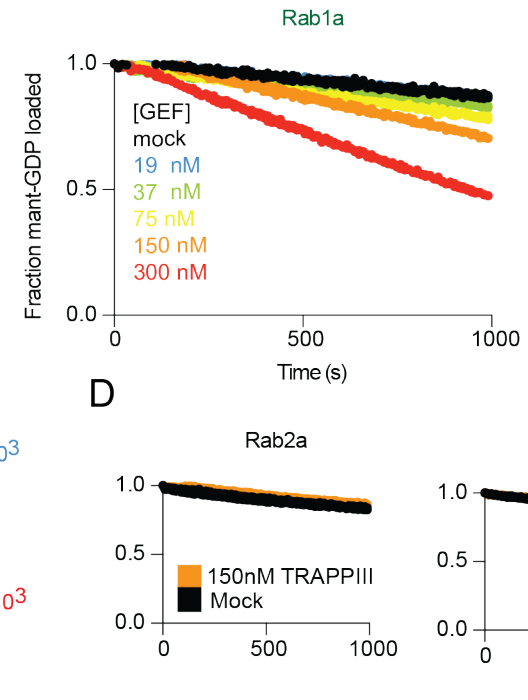

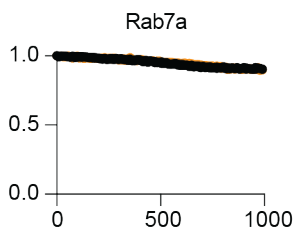

Rab14
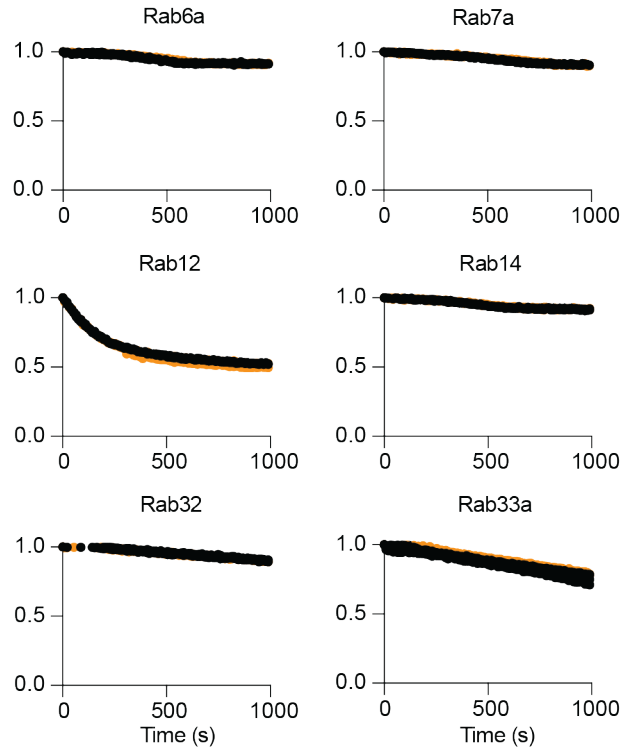
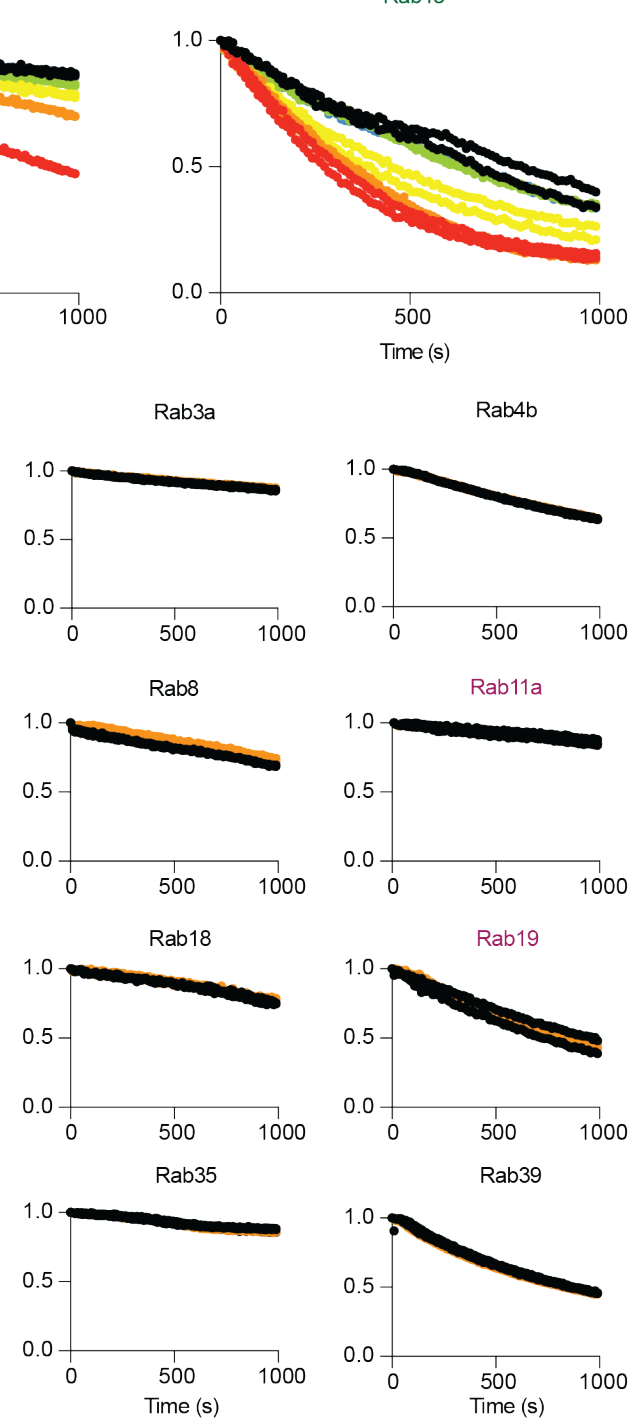

183 Figure 2. Biochemical analysis of the mammalian TRAPPIII complex against a panel

184 of different Rab GTPases.

185 A. A simplified Rab evolutionary schematic (based on [28]). Rabs are colored according

186 to their TRAPPII and TRAPPIII GEF activity.

187 B. In-vitro GEF assay of TRAPPIII on Rab1a and Rab43. Nucleotide exchange was

188 monitored by measuring the fluorescent signal during the TRAPPIII (19nM-300nM) 
189 catalyzed release of Mant-GDP from $4 \mu \mathrm{M}$ of Rab-His6 in the presence of $100 \mu \mathrm{M}$

190 GTPYS. Each concentration was conducted in duplicate $(n=2)$.

191 C. Nucleotide exchange rates of Rab1 and Rab43 plotted as a function of TRAPPIII

192 concentration $(n=2)$.

193 D. In vitro GEF assay of TRAPPIII on the panel of Rab GTPases. $4 \mu \mathrm{M}$ Rab was loaded

194 with Mant-GDP in the presence of 150nM TRAPPIII. Each concentration was either

195 conducted in duplicate or triplicate ( $n=3$ for Rab11a, Rab11b, Rab18, Rab19, Rab33,

196 Rab35, $\mathrm{n}=2$ for the others).

Determining conformational differences upon Rab1 binding to mammalian

TRAPPIII

We carried out HDX-MS experiments of TRAPPIII binding to Rab1 to understand

201 the molecular basis for how TRAPPIII binds to and activates Rab1. HDX-MS measures

202 the exchange rate of amide hydrogens in solution, with the rate being primarily

203 determined by stability of secondary structure. It is a powerful tool to measure protein

204 conformational dynamics. Deuterium incorporation in HDX-MS requires the generation of

205 pepsin peptide fragments spanning the entire complex. We obtained peptide maps

206 spanning $69-97 \%$ of the entire complex (Core: TRAPPC1, TRAPPC2, TRAPPC2L,

207 TRAPPC3, TRAPPC4, TRAPPC5, TRAPPC6A; TRAPPII specific: TRAPPC9,

208 TRAPPC10; TRAPPIII specific: TRAPPC8, TRAPPC11, TRAPPC12, TRAPPC13), with

209 specific coverage values listed in Table S2-S4. Significant differences in exchange 
210 between conditions were defined as differences at any timepoint fitting the following three

211 criteria ( $>5 \%,>0.5 \mathrm{Da}$, and two tailed T-test $\mathrm{p}$ value $<0.01)$.

212 HDX-MS experiments were performed in the presence of EDTA to generate a

213 nucleotide free stabilised Rab-GEF complex. Experiments were carried out under three

214 conditions: EDTA treated Rab, TRAPPIII alone, and TRAPPIII bound to Rab1. We

215 observed decreased exchange upon formation of the Rab-TRAPPIII complex in

216 TRAPPC4 (5-19, 112-136, 180-191) and Rab1a (49-79) (Fig. 3B+C). There were multiple

217 regions with increased exchange in Rab1a (12-40, 91-108, 116-165), likely driven by GEF

218 mediated nucleotide loss. The full HDX-MS data for all subunits and Rab1a is outlined in

219 the source data. Decreases in exchange in TRAPPC4 (180-191) mapped onto the

220 putative Rab binding site consistent with this peptide being protected when Rab was

221 incubated with TRAPPII [10]. Decreases in exchange in Rab1 were observed in the

222 interswitch and switchll regions upon binding the complex (49-79) (Fig. 3B+C). Rab1 was

223 also destabilized in the nucleotide binding pocket as would be expected with the loss of

224 nucleotide upon binding its GEF. No other significant changes were observed in the

225 TRAPPIII complex upon Rab binding. These results suggest that both mammalian

226 TRAPPII and TRAPPIII complexes are binding Rabs at a similar interface. 
A

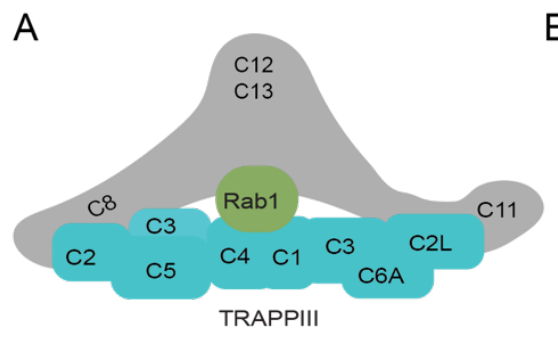

TRAPPC4

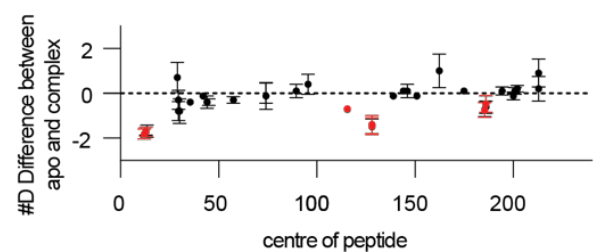

B $\quad$ Rab

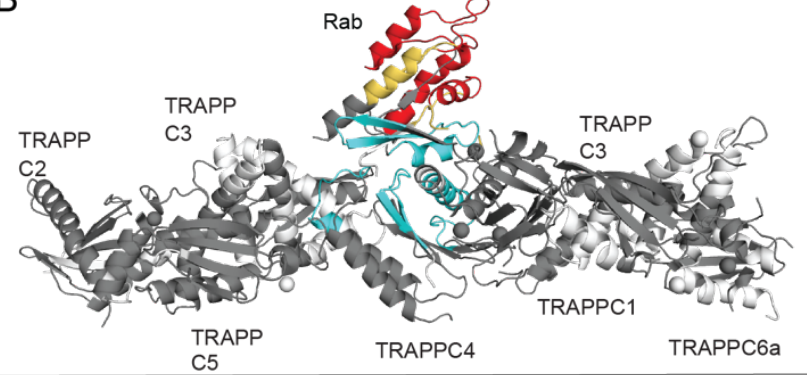

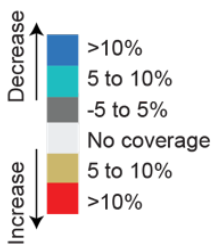

Rab1

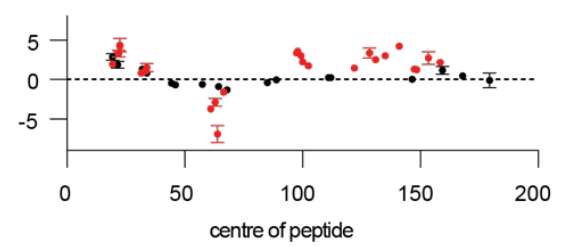

- No significant difference between apo and Rab bound

Significant difference

between apo and Rab bound

229 Figure 3. Defining the Rab binding site in the mammalian TRAPPIII complex

230 A. Cartoon schematic highlighting TRAPPIII with bound Rab GTPase.

231 B. Significant differences in HDX observed across all time points when Rab1 was

232 incubated with TRAPPIII are mapped onto the predicted model of the TRAPP core.

233 Regions with differences are coloured according to the legend.

234 C. The number of deuteron differences for all analysed peptides over the entire deuterium

235 exchange time course for TRAPPIII in the presence of Rab1 $(n=3)$. Only subunits with

236 significant differences (defined as $>5 \%,>0.5 \mathrm{Da}$, two tailed T-test $p$ value $<0.01$ ), are

237 shown. Every point represents the central residue of an individual peptide with significant

238 differences being indicated by points colored red.

241 Dynamic differences exist at the Rab binding site of the core subunits in the 
We carried out hydrogen deuterium exchange mass spectrometry (HDX-MS)

244 experiments comparing TRAPPII vs TRAPPIII to understand any conformational

245 differences that occur in the core between the two complexes. H/D exchange differences

246 between TRAPPII and TRAPPIII can be analyzed only in the shared core components.

247 Multiple different subunits had significant differences in deuterium exchange. TRAPPIII

248 was more protected than TRAPPII in TRAPPC2L (72-80, 100-135), and TRAPPC4 (137-

249 155, 170-204) (Fig 4B). TRAPPII was more protected than TRAPPIII in TRAPPC2 (47-

250 53, 59-70), TRAPPC2L (17-25, 37-66, 81-99), TRAPPC4 (65-83) and TRAPPC5 (58-69,

251 180-188) (Fig 4B). The full HDX-MS data for all subunits is summarized in the source

252 data. The TRAPPIII complex was more protected than TRAPPII at the canonical Rab

253 interface in TRAPPC4 (170-204). This region in TRAPPC4 would likely be in contact with

254 the $\mathrm{N}$ and $\mathrm{C}$ termini of the Rab substrate (Fig 4C). Intriguingly, this is in the same region

255 that was protected in TRAPPC4 (181-191) with Rab1a (Fig 3C). The large protections

256 observed in the TRAPPC2L subunit are likely due to interactions with TRAPPIII specific

257 subunits which is consistent with cryo-EM data showing TRAPPC2L being at the interface

258 with TRAPPC11 in the Drosophila TRAPPIII complex [24]. Regions of TRAPPC2 were

259 more protected in the TRAPPII complex, which is unexpected since this is the putative

260 binding interface for the TRAPPIII specific subunit TRAPPC8. Together these data

261 suggest that TRAPPII and TRAPPIII have dynamic differences in their core subunits that

262 are involved in Rab binding, which may be playing a role in mediating Rab specificity. 

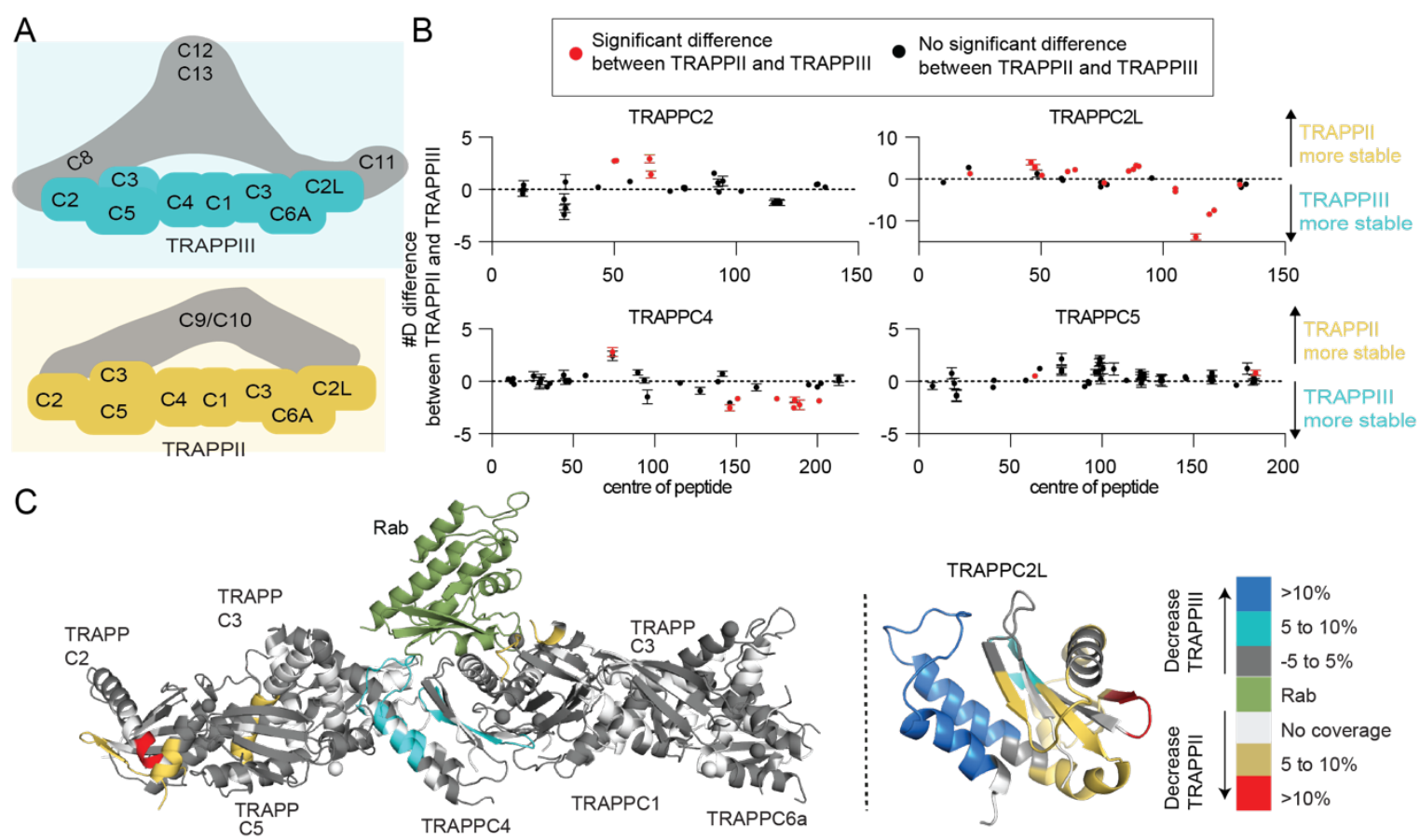

Figure 4. Comparative HDX-MS reveals dynamic differences within the core of TRAPPIII compared to TRAPPII

267 A. Cartoon schematic highlighting protections or destabilisations in TRAPPII and 268 TRAPPIII.

269 B. The number of deuteron differences for all analysed peptides over the entire deuterium 270 exchange time course for TRAPPIII compared to TRAPPII $(n=3)$. Red points indicate 271 peptides with significant differences (defined as $>5 \%,>0.5 \mathrm{Da}$, two tailed T-test $p$ value $272<0.01)$ in HDX. Only subunits with significant differences between complexes are shown.

273 The full H/D exchange data is summarized in the source data. Increases in the number 274 of deuterons indicates a stabilization in TRAPPII while a decrease in the number of 275 deuterons indicates a stabilization in TRAPPIII. Every point represents the central residue 276 of an individual peptide. 
277 C. Significant differences in HDX between the TRAPP complexes are mapped on to the

278 core and TRAPPC2L model, with Rab shown to illustrate the binding interface. Increases

279 in exchange are regions that are more stable in TRAPPII, with decreases in exchange

280 representing regions that are more stable in TRAPPIII. Regions with differences are

281 coloured according to the legend. The exact molecular details for how TRAPPC2L

282 associate with the core is unknown, however, it is proposed to bind TRAPPC6, and is

283 positioned on this side of the complex [24].

The C-terminus of Rab GTPases is not the sole determinant of selectivity for

mammalian TRAPP complexes

The conformational differences observed in the TRAPPC4 subunit between

TRAPPII and TRAPPIII at a region that interacts with the $\mathrm{N}$-terminus and $\mathrm{C}$-terminus of

Rab substrates led us to investigate the potential role of the Rab C-terminus in controlling substrate specificity. We generated two chimeras of both Rab1 and Rab11 where we

291 replaced part of the C-terminal helix and the entire hyper-variable tail (Fig. 5A+B). We

292 conducted GEF assays using TRAPPIII against the four different constructs and found

293 that changing the C-terminus of Rabs did not alter the substrate specificity, with no activity

294 at all against Rab11 with different C-termini, and slightly increased activity with toward

295 Rab1A with the chimeric Rab11A C-termini (Fig. 5C). The hyper-variable tail of Rabs play

296 an essential role in controlling Rab selectivity in the yeast TRAPPII and TRAPPIII

297 complexes, with this mediated by a steric gating mechanism [27]. The chimera data with

298 mammalian TRAPP complexes reveals that there is some determinant of Rab selectivity 
299 that is independent of the C-termini and may be driven either by conformational changes

300 in the Rab binding site, or additional interactions between the TRAPPII or TRAPPIII

301 specific subunits and the substrate Rabs.

302

A

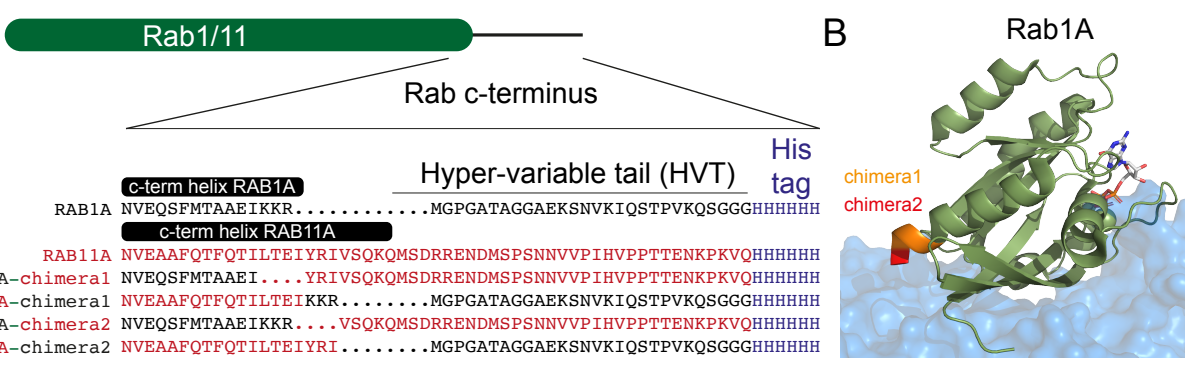

B Rab1A Rab11A
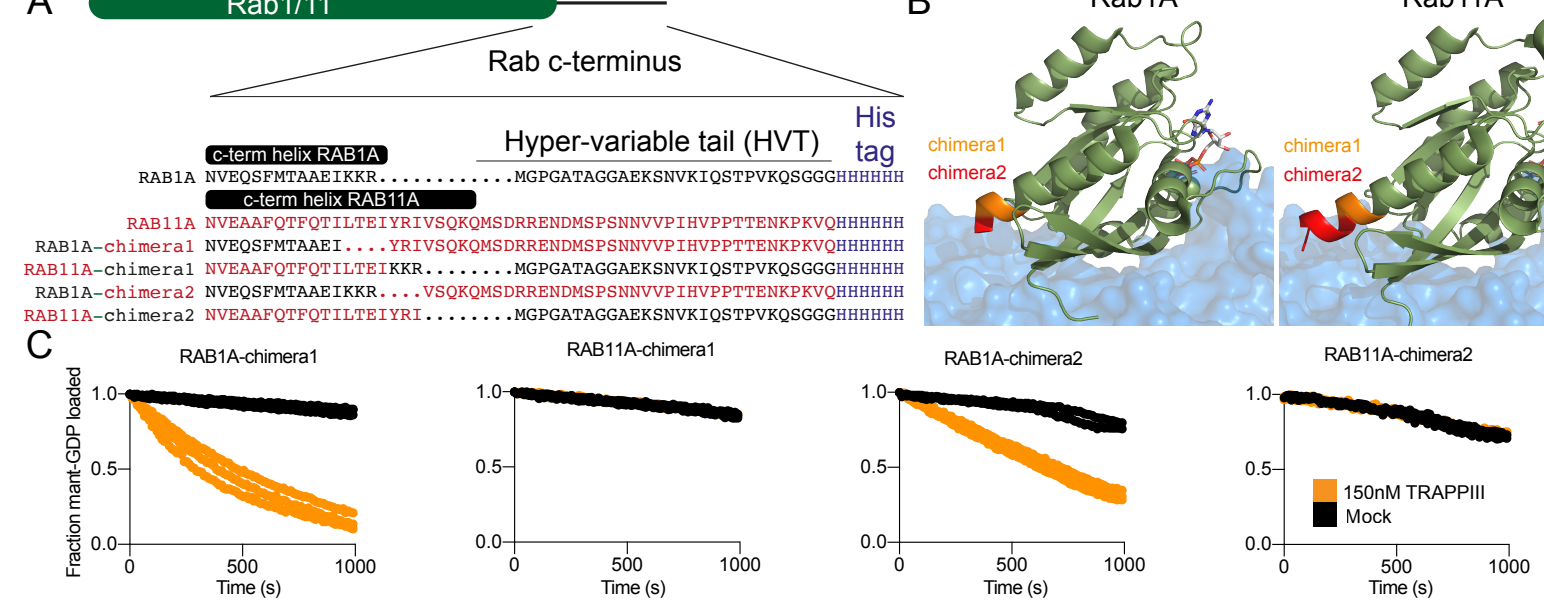

Figure 5. The C-terminus of Rab1A and Rab11 is not the major determinant of Rab

306 A. Alignment of the C-terminus of Rab1A and Rab11A, covering the C-terminal helix of

307 the Nucleotide binding domain, and the hyper-variable tail. The lipidated cysteine residue

308 is replaced by a his-tag, to allow for Ni-NTA mediated coupling to membranes. Chimeras

309 of Rab1 and Rab11 were generated replacing the C-terminus of Rabs as indicated by the

310 sequence alignment. Rab1A sequence is in black, with the Rab11A sequence in red.

311 B. Structures of Rab1A (pdb: 3tkl) [29] and Rab11A (pdb: 6djl) [30] with the approximate

312 position of the TRAPP core as described in Cai et al (pdb: 3cue) [22] The colors indicate

313 the locations where the sequence is swapped for the two chimeras.

314 C. In vitro GEF assay of TRAPPIII against Rab1a and Rab11a c-terminal chimeras. $4 \mu \mathrm{M}$

315 Rab was loaded with Mant-GDP in the presence of $150 \mathrm{nM}$ TRAPPIII. Control 
316 experiments without GEF present were conducted in duplicate for Rab1A and

317 Rab11A chimera1 $(n=2)$, all other concentrations and controls for all other experiments

318 were done in triplicate $(n=3)$.

Membrane binding enhances GEF activity of TRAPPII and TRAPPII, and leads to

321 extensive conformational changes

To investigate the role that membranes play in altering TRAPPII and TRAPPIII Rab activity we compared TRAPPII and TRAPPIII mediated GEF activity of Rab1 on extruded

liposomes and conducted HDX-MS experiments examining conformational changes that occur upon membrane binding for both TRAPII and TRAPPIII. We tested TRAPPII's and

326 TRAPPIII's ability to activate Rab1a on synthetic membranes, with both having enhanced

327 GEF activity. The TRAPPIII complex was more active than TRAPPII with membrane

328 localised Rab1a (43.2 $\times 10^{3} \mathrm{M}^{-1} \mathrm{~S}^{-1}$ vs $8.8 \times 10^{3} \mathrm{M}^{-1} \mathrm{~s}^{-1}$ respectively, Fig. $\left.6 \mathrm{~A}+\mathrm{B}\right)$. This is

329 consistent with TRAPPIII being the primary activator of Rab1 in-vivo and further validates

330 that TRAPP complexes are more efficient GEFs when their substrates are presented on

331 a membrane surface.

Increased GEF activity on membrane surfaces could be mediated by a multitude

333 of mechanisms. Activity could be enhanced by increased local concentration of GEF and

334 substrate on membranes, and/or conformational changes in the TRAPP complex may

335 occur upon membrane binding. We compared differences in HDX-MS upon membrane 
337 PC, 10\% PI, 15\% PE, 10\% PS, 10\% DGS NTA, 10\% PI(4)P, mimicking the composition 338 of the trans Golgi network (TGN).

339 Numerous differences were observed in multiple subunits of both TRAPPII and

340 TRAPPIII in the presence of liposomes (Fig. 6D+E). There was decreased exchange in

341 TRAPPIII in TRAPPC8 $(5-21,115-126,376-421,440-457,471-487,492-498)$ and

342 increased exchange was observed in TRAPPC4 (181-191), TRAPPC8 (24-62, 340-350,

$343588-620,643-647,710-720,759-767,981-992,1105-1139,1159-1198,1266-1284$,

344 1369-1380), TRAPPC11 (13-25, 74-96, 120-139, 152-161, 193-259, 266-281, 312-338,

345 349-373, 405-477, 612-621, 773-852, 882-889, 1056-1066), TRAPPC12 (341-358, 382-

$346399,701-716)$, and TRAPPC13 (119-127, 311-327, 375-387).

347 We observed increased exchange in TRAPPII upon membrane binding in

348 TRAPPC2L (8-16, 56-66), TRAPPC5 (51-69), TRAPPC9 (68-80, 87-99, 160-180, 311 -

$349322,352-363,890-896,1006-1033)$ and TRAPPC10 (30-37, 95-124, 149-162, 272-310,

$350374-381,397-423,469-487,489-562,740-760,1093-1112,1133-1147)$. The full list of

351 HDX-MS data for all subunits is compiled in the source data. The decreased exchange

352 observed in TRAPPC8 upon membrane binding (5-21, 115-126, 376-421, 440-457, 471-

$353487,492-498$ ) could be contact sites between TRAPPC8 and membrane or interactions

354 between TRAPPC8 and different subunits that are enhanced in the presence of

355 membranes. The protection in TRAPPC8 (376-421) in the presence of liposomes is

356 consistent with a conserved amphipathic helix present in the yeast TRAPPC8 homolog

357 trs85 (368-409) that was found to be important for membrane binding [23]. This region is 
358 highly conserved (Fig. S3) and reveals a key role of TRAPPC8 in driving membrane

359 binding of TRAPPIII.

360 Increased exchange was observed in the TRAPPIII complex specific subunits

361 (TRAPPC8, TRAPPC11, TRAPPC12, TRAPPC13), and the TRAPPII complex specific

362 subunits (TRAPPC9, TRAPPC10) as well as in the core subunits TRAPPC2L, TRAPPC4,

363 and TRAPPC5 suggesting that large conformational changes occur upon membrane

364 binding. The increased exchange in the core subunits of TRAPPIII (TRAPPC4) include

365 regions that span the Rab binding site (TRAPPC4 181-191) and reveal a possible

366 conformational driven mechanism of activation of TRAPP GEF activity on membranes.
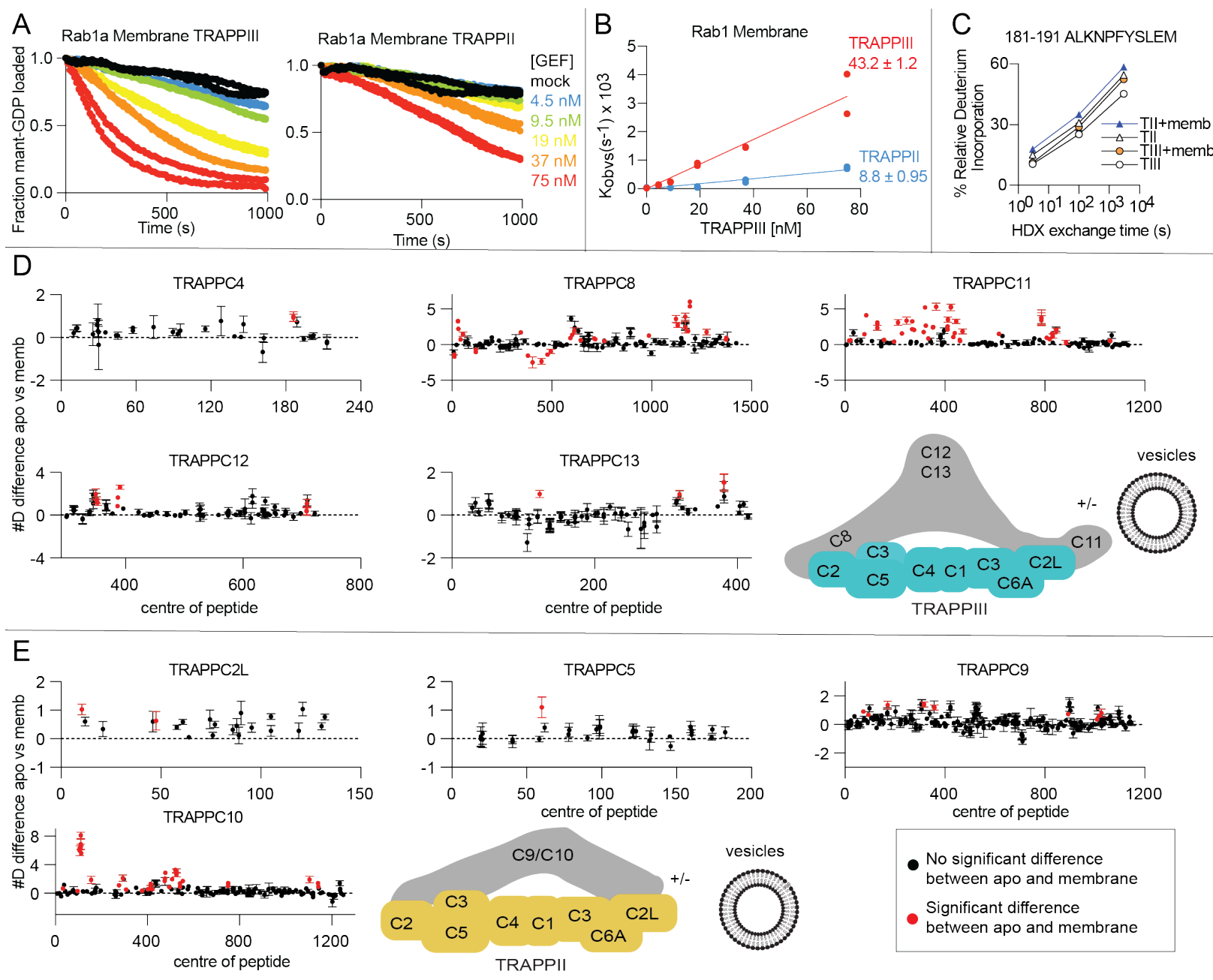
368 Figure 6. Membrane binding increases GEF activity of both TRAPPII and TRAPPIII, and leads to large scale conformational changes

370 A. In vitro GEF assay of TRAPPIII and TRAPPII at various concentrations (4.5nM $-75 n M)$

371 against Rab1a $(4 \mu \mathrm{M})$ in the presence or absence of $150 \mathrm{~nm}$ extruded liposomes at

$3720.2 \mathrm{mg} / \mathrm{ml}(45 \% \mathrm{PC}, 10 \% \mathrm{PI}, 15 \% \mathrm{PE}, 10 \% \mathrm{PS}, 10 \%$ DGS NTA, 10\% PI(4)P, $n=2)$.

373 B. Nucleotide exchange rates of Rab1 plotted as a function of TRAPP concentration $374 \quad(n=2)$

375 C. Changes in percent deuterium exchange of the TRAPPC4 peptide 181-191 for

376 TRAPPIII (TIII) with and without membrane and TRAPPII (TII) with and without 377 membrane.

378 D. The number of deuteron difference for all analysed peptides over the entire deuterium 379 exchange time course for TRAPPIII in the presence and absence of $150 \mathrm{~nm}$ extruded 380 liposomes (45\% PC, 10\% PI, 15\% PE, 10\% PS, 10\% DGS NTA, 10\% PI(4)P) ( $n=3)$. Only 381 subunits with significant differences are shown (defined as $>5 \%,>0.5 \mathrm{Da}$, two tailed T382 test $p$ value $<0.01$ ). Every point represents the central residue of an individual peptide 383 with significant differences indicated in red.

384 E. The number of deuteron difference for all analysed peptides over the entire deuterium 385 exchange time course for TRAPPII in the presence and absence of $150 \mathrm{~nm}$ extruded 386 liposomes (45\% PC, 10\% PI, 15\% PE, 10\% PS, 10\% DGS NTA, 10\% PI(4)P) (n=3). Only 387 subunits with significant differences are shown (defined as $>5 \%,>0.5 \mathrm{Da}$, two tailed T-test $388 \mathrm{p}$ value $<0.01)$. Every point represents the central residue of an individual peptide with 389 significant differences indicated in red. 


\section{Discussion}

The TRAPPII and TRAPPIII complexes play critical roles in activating Rab

394 GTPases during membrane trafficking processes, with these complexes being conserved

395 in all Eukaryotes. They have well established roles in a diverse set of pathways including 396 secretion, ER-Golgi transport and autophagy [13-16,31]. Many biochemical and 397 structural studies have revealed the architecture of these complexes in both yeast and 398 metazoans showing how these complexes are assembled and how they bind and activate 399 Rab GTPases [14,18,22,32-34]. However, the exact molecular details for TRAPP 400 complex Rab substrate selectivity and membrane activation is still ambiguous. Our 401 biophysical and biochemical analysis of the mammalian TRAPPIII complex has revealed 402 novel insight into TRAPPIII substate specificity, how complex specific subunits alter the 403 Rab binding interface of the core, and how membranes lead to large scale conformational 404 changes in both TRAPPII and TRAPPIII.

406 and Rab43 [10]. The TRAPPIII complex is a well validated GEF for Rab1a $[11,14,15,35]$,

407 however, the substrate specificity towards other Rab GTPases for mammalian TRAPPIII 408 is unknown. We find that mammalian TRAPPIII has activity towards Rab1a and a novel 409 activity towards Rab43. There was no detectable GEF activity for Rab19 or the other 17 410 Rab GTPases tested. The observation that TRAPPIII is a GEF for Rab43 but not Rab19 411 is intriguing since Rab43 and Rab19 are in the Rab1a family and are very evolutionarily 
412 similar [28]. TRAPPII was equally active against both Rab43 and Rab19, revealing an

413 additional substrate selectivity between TRAPPII and TRAPPIII. Extensive sequence

414 analysis between Rab1/Rab43 with Rab19/Rab11 does not reveal a simple difference for

415 how TRAPPII and TRAPPIII obtain substrate selectivity. Further biochemical and high

416 resolution structural data will be required to decipher the exact molecular mechanism of

417 Rab specificity.

418 Multiple conformational differences were observed between TRAPPII and

419 TRAPPIII in the shared subunits. TRAPPIII was more stable at the Rab-binding interface

420 compared with TRAPPII, which suggests initial insight into a possible mechanism for how

421 these complexes can mediate Rab specificity. The C-terminus of TRAPPC4 was more

422 stable in TRAPPIII, with these being very similar regions to those protected upon Rab

423 binding in TRAPPIII and TRAPPII (180-191 in TRAPPC4) [10]. It's possible that this

424 alteration in the conformation of the putative Rab binding site prevents association with

425 either Rab11 or Rab19 for TRAPPIII. The recent Cryo-EM structure of Drosophila

426 TRAPPIII allowed for a comparison between the two complexes seen in the mammalian

427 complexes [24]. Intriguingly, the interfaces identified between TRAPPC2 with TRAPPC8

428 and TRAPPC2L with TRAPPC11 identified in the Drosophila TRAPPIII cryo-EM structure

429 were more protected from H/D exchange in TRAPPII compared to TRAPPIII. This

430 suggests that there are shared interfaces between the core and the TRAPPII and

431 TRAPPIII unique subunits. Further details of the differences will require high resolution

432 structural data of the TRAPPII complex. 
Rab substrates had increased activity in the presence of synthetic membranes for

434 both TRAPPII and TRAPPIII, consistent with studies of the yeast TRAPPII and TRAPPIII

435 complexes [14]. The TRAPPIII complex activated Rab1a significantly faster in the

436 presence of membranes compared to TRAPPII which is consistent with TRAPPIII being

437 the primary activator of Rab1 in-vivo. This increased activity may be driven by the

438 membrane binding site identified in HDX-MS studies in TRAPPC8. We found multiple

439 peptides with significant protections spanning TRAPPC8 including the region 376-421.

440 This region corresponds to an amphipathic helix (368-409) discovered in yeast Trs85,

441 where mutants of this region decreased membrane recruitment and Rab activation [23].

442 This highlights a conserved role throughout evolution of the TRAPPC8 subunit in

443 mediating membrane association and activation of Rab1. Multiple TRAPPII and TRAPPIII

444 specific subunits were destabilised upon membrane binding. These increases in

445 exchange are likely driven by conformational rearrangements of the subunit-subunit

446 interacting regions. Further detailed structural studies will help interpret how these

447 changes may mediate membrane binding or alter GEF activity.

448 The emerging set of clinical mutations in either TRAPP core or complex specific

449 subunits demonstrates the important roles that both TRAPPII and TRAPPIII play in

450 membrane trafficking [5,6,9,36]. Interestingly, our HDX-MS experiments revealed

451 conformational differences between TRAPPII and TRAPPIII located at or near these sites

452 of mutations. These differences occurred in TRAPPC2 and TRAPPC2L. The mutations

453 D47Y, H80R, and F83S in TRAPPC2 have been associated with the skeletal disorder

454 spondyloepiphyseal dysplasia tarda (SEDT; also abbreviated SEDL) [37,38]. TRAPPII 
455 was protected compared to TRAPPIII in peptides spanning 47-53 and 59-70 of

456 TRAPPC2. The D47Y mutation has been shown to disrupt both the TRAPPIII and

457 TRAPPII complexes through disrupting the interactions between TRAPPC2 with

458 TRAPPC9 or TRAPPC8 [37] with the equivalent D46Y mutation in yeast only disrupting

459 the TRAPPIII complex [38]. The mutation D37Y in TRAPPC2L has been associated with

460 neurodevelopmental delay [39]. The equivalent yeast mutant (D45Y) disrupts the

461 interaction between TRAPPC2L and the TRAPPII specific subunit TRAPPC10 [39]. We

462 found large stabilisations in TRAPPII compared to TRAPPIII in a peptide spanning 37-58

463 which would be consistent with this mutation disrupting the TRAPPC2L-TRAPPC10

464 interaction. These differences between TRAPPII and TRAPPIII at these important

465 residues indicate that the clinical mutants could possibly target TRAPPII and TRAPPIII

466 differently depending on unique interactions with complex specific subunits.

HDX-MS experiments examining differences upon membrane binding revealed

468 secondary structure differences at or near regions mutated in human disease, specifically

469 in TRAPPC9 and TRAPPC11. The mutation L178P in TRAPPC9 has been implicated

470 with severe intellectual disability [40]. HDX-MS experiments comparing apo-TRAPPII to

471 membrane bound TRAPPII showed an exposure in a peptide spanning 160-180.

472 Furthermore, the mutations Q284P and Q777P of TRAPPC11 have been implicated in

473 muscular disorders by elevated creatine kinase levels and cerebral atrophy $[41,42]$ and

474 we found that TRAPPC11 was exposed in the peptides 266-281 and 773-801. The 475 peptide spanning 266-281 lies extremely close to the Q284 residue and the peptide 476 spanning 773-801 completely contains the Q777 residue. These secondary structure 
477 differences could indicate that these clinical mutants alter the membrane activation of

478 both TRAPPII and TRAPPIII complexes. More research is needed to investigate the exact

479 molecular mechanisms of these clinical mutants and how they alter TRAPP's function.

480 The TRAPP complexes are some of the most important regulators of membrane

481 trafficking and activators of Rabs at the Golgi. Our data highlights the critical dynamic

482 differences between the two complexes at the Rab binding site which likely has a role in

483 regulating Rab specificity. Continued biochemical and structural studies will be required

484 to decipher the exact mechanism of this specificity with this work helping provide a strong

485 start point for these future studies.

486

487 Acknowledgements

488 This work in the Burke lab was supported by Natural Science and Engineering Research

489 Council (NSERC Discovery Grant 2020-04241), and a Michael Smith Foundation for

490 Health Research Scholar award (17868). C.K.Y. is supported by CIHR (FDN-143228) and

491 the Natural Sciences and Engineering Research Council of Canada (RGPIN-2018-

492 03951). This research project was supported in part by the UBC High Resolution

493 Macromolecular Cryo-Electron Microscopy Facility (HRMEM).

495 Contributions

496 JEB, $\mathrm{NH}$ and MLJ designed all biophysical/biochemical experiments. NH cloned the

497 TRAPPIII complex. NH, MP and MLJ carried out protein expression/purification. NH and 
498 MLJ carried out all biochemical studies. NH, MLJ, KDF and MP carried out HDX-MS

499 experiments. UD SEN and CKY carried out electron microscopy studies. NH, MLJ, and

500 JEB wrote the manuscript with input from all authors.

\section{References}

503 [1] J. Cherfils, M. Zeghouf, Regulation of Small GTPases by GEFs, GAPs, and GDIs,

$504 \quad$ Physiological Reviews. 93 (2013) 269-309.

505

[2] M.P. Müller, R.S. Goody, Molecular control of Rab activity by GEFs, GAPs and GDI,

Small GTPases. 9 (2018) 5-21. https://doi.org/10.1080/21541248.2016.1276999.

[3] P. Novick, Regulation of membrane traffic by Rab GEF and GAP cascades, Small GTPases. 7 (2016) 252-256. https://doi.org/10.1080/21541248.2016.1213781.

[4] J. Barrowman, D. Bhandari, K. Reinisch, S. Ferro-Novick, TRAPP complexes in

513 [5] S. Brunet, M. Sacher, In Sickness and in Health: The Role of TRAPP and https://doi.org/10.1111/tra.12183.

[6] J.J. Kim, Z. Lipatova, N. Segev, TRAPP Complexes in Secretion and Autophagy, Front. Cell Dev. Biol. 4 (2016). https://doi.org/10.3389/fcell.2016.00020. 
[8] M. Sacher, Y.-G. Kim, A. Lavie, B.-H. Oh, N. Segev, The TRAPP Complex: Insights into its Architecture and Function, Traffic. 9 (2008) 2032-2042. https://doi.org/10.1111/j.1600-0854.2008.00833.x.

[9] M. Sacher, N. Shahrzad, H. Kamel, M.P. Milev, TRAPPopathies: An emerging set of disorders linked to variations in the genes encoding transport protein particle (TRAPP)-associated proteins, Traffic. 20 (2019) 5-26. https://doi.org/10.1111/tra.12615.

[10] M.L. Jenkins, N.J. Harris, U. Dalwadi, K.D. Fleming, D.S. Ziemianowicz, A. Rafiei, E.M. Martin, D.C. Schriemer, C.K. Yip, J.E. Burke, The substrate specificity of the human TRAPPII complex's Rab-guanine nucleotide exchange factor activity, Communications Biology. 3 (2020) 1-12. https://doi.org/10.1038/s42003-020-

[11] F. Riedel, A. Galindo, N. Muschalik, S. Munro, The two TRAPP complexes of metazoans have distinct roles and act on different Rab GTPases, Journal of Cell Biology. 217 (2017) 601-617. https://doi.org/10.1083/jcb.201705068.

[12] L.L. Thomas, J.C. Fromme, GTPase cross talk regulates TRAPPII activation of Rab11 homologues during vesicle biogenesis, Journal of Cell Biology. 215 (2016)

[13] N. Morozova, Y. Liang, A.A. Tokarev, S.H. Chen, R. Cox, J. Andrejic, Z. Lipatova, V.A. Sciorra, S.D. Emr, N. Segev, TRAPPII subunits are required for the specificity switch of a Ypt-Rab GEF, Nature Cell Biology. 8 (2006) 1263-1269. https://doi.org/10.1038/ncb1489. 
[14] L.L. Thomas, A.M.N. Joiner, J.C. Fromme, The TRAPPIII complex activates the GTPase Ypt1 (Rab1) in the secretory pathway, Journal of Cell Biology. 217 (2017) 283-298. https://doi.org/10.1083/jcb.201705214.

[15] M.A. Lynch-Day, D. Bhandari, S. Menon, J. Huang, H. Cai, C.R. Bartholomew, J.H. Brumell, S. Ferro-Novick, D.J. Klionsky, Trs85 directs a Ypt1 GEF, TRAPPIII, to the phagophore to promote autophagy, PNAS. 107 (2010) 7811-7816. https://doi.org/10.1073/pnas.1000063107.

[16] K. Meiling-Wesse, U.D. Epple, R. Krick, H. Barth, A. Appelles, C. Voss, E.-L. Eskelinen, M. Thumm, Trs85 (Gsg1), a Component of the TRAPP Complexes, Is Required for the Organization of the Preautophagosomal Structure during Selective Autophagy via the Cvt Pathway*, Journal of Biological Chemistry. 280 (2005)

[17] C. Li, Z. Wei, Y. Fan, W. Huang, Y. Su, H. Li, Z. Dong, M. Fukuda, M. Khater, G. Sorting of GPCRs, Cell Rep. 21 (2017) 1089-1101. https://doi.org/10.1016/j.celrep.2017.10.011.

[18] Y.-G. Kim, S. Raunser, C. Munger, J. Wagner, Y.-L. Song, M. Cygler, T. Walz, B.H. Oh, M. Sacher, The Architecture of the Multisubunit TRAPP I Complex Suggests 
McManus, J.S. Weissman, A Systematic Mammalian Genetic Interaction Map

Reveals Pathways Underlying Ricin Susceptibility, Cell. 152 (2013) 909-922. https://doi.org/10.1016/j.cell.2013.01.030.

[20] P.J. Scrivens, B. Noueihed, N. Shahrzad, S. Hul, S. Brunet, M. Sacher, C4orf41 and TTC-15 are mammalian TRAPP components with a role at an early stage in ER-to-Golgi trafficking, MBoC. 22 (2011) 2083-2093. https://doi.org/10.1091/mbc.e10-11-0873.

[21] C.A. Lamb, S. Nühlen, D. Judith, D. Frith, A.P. Snijders, C. Behrends, S.A. Tooze, TBC1D14 regulates autophagy via the TRAPP complex and ATG9 traffic, The

[22] Y. Cai, H.F. Chin, D. Lazarova, S. Menon, C. Fu, H. Cai, A. Sclafani, D.W. EMBO Journal. 35 (2016) 281-301. https://doi.org/10.15252/embj.201592695. Rodgers, E.M. De La Cruz, S. Ferro-Novick, K.M. Reinisch, The Structural Basis for Activation of the Rab Ypt1p by the TRAPP Membrane-Tethering Complexes, Cell. 133 (2008) 1202-1213. https://doi.org/10.1016/j.cell.2008.04.049.

[23] A.M.N. Joiner, B.P. Phillips, K. Yugandhar, E.J. Sanford, M.B. Smolka, H. Yu, E.A. 583 of metazoan TRAPPIII, the multisubunit complex that activates the GTPase Rab1, Miller, J.C. Fromme, Structure and mechanism of TRAPPIII-mediated Rab1 activation, BioRxiv. (2020) 2020.10.08.332312. https://doi.org/10.1101/2020.10.08.332312.

[24] A. Galindo, V.J. Planelles-Herrero, G. Degliesposti, S. Munro, A cryo-EM structure BioRxiv. (2020) 2020.12.17.423307. https://doi.org/10.1101/2020.12.17.423307. 
[25] F. Weissmann, G. Petzold, R. VanderLinden, P.J.H. in 't Veld, N.G. Brown, F. Lampert, S. Westermann, H. Stark, B.A. Schulman, J.-M. Peters, biGBac enables rapid gene assembly for the expression of large multisubunit protein complexes, PNAS. 113 (2016) E2564-E2569. https://doi.org/10.1073/pnas.1604935113.

[26] L.A. Kelley, S. Mezulis, C.M. Yates, M.N. Wass, M.J.E. Sternberg, The Phyre2 web portal for protein modeling, prediction and analysis, Nature Protocols. 10 (2015) 845-858. https://doi.org/10.1038/nprot.2015.053.

[27] L.L. Thomas, S.A. van der Vegt, J.C. Fromme, A Steric Gating Mechanism Dictates the Substrate Specificity of a Rab-GEF, Developmental Cell. 48 (2019) 100-114.e9. https://doi.org/10.1016/j.devcel.2018.11.013.

[28] T.H. Klöpper, N. Kienle, D. Fasshauer, S. Munro, Untangling the evolution of Rab G proteins: implications of a comprehensive genomic analysis, BMC Biol. 10 (2012) 71. https://doi.org/10.1186/1741-7007-10-71.

[29] W. Cheng, K. Yin, D. Lu, B. Li, D. Zhu, Y. Chen, H. Zhang, S. Xu, J. Chai, L. Gu, Structural insights into a unique Legionella pneumophila effector LidA recognizing both GDP and GTP bound Rab1 in their active state, PLoS Pathog. 8 (2012) e1002528. https://doi.org/10.1371/journal.ppat.1002528.

[30] M.L. Jenkins, J.P. Margaria, J.T.B. Stariha, R.M. Hoffmann, J.A. McPhail, D.J. Hamelin, M.J. Boulanger, E. Hirsch, J.E. Burke, Structural determinants of Rab11 activation by the guanine nucleotide exchange factor SH3BP5, Nat Commun. 9 (2018) 3772. https://doi.org/10.1038/s41467-018-06196-z. 
606

607

608

609

610

611

612

613

614

615

616

[31] D. Taussig, Z. Lipatova, N. Segev, Trs20 is Required for TRAPP III Complex Assembly at the PAS and its Function in Autophagy, Traffic. 15 (2014) 327-337. https://doi.org/10.1111/tra.12145.

[32] M. Pinar, E. Arias-Palomo, V. de los Ríos, H.N.A. Jr, M.A. Peñalva, Characterization of Aspergillus nidulans TRAPPs uncovers unprecedented similarities between fungi and metazoans and reveals the modular assembly of TRAPPII, PLOS Genetics. 15 (2019) e1008557. https://doi.org/10.1371/journal.pgen.1008557.

[33] D. Tan, Y. Cai, J. Wang, J. Zhang, S. Menon, H.-T. Chou, S. Ferro-Novick, K.M. Reinisch, T. Walz, The EM structure of the TRAPPIII complex leads to the identification of a requirement for COPII vesicles on the macroautophagy pathway, PNAS. 110 (2013) 19432-19437. https://doi.org/10.1073/pnas.1316356110.

[34] C.K. Yip, J. Berscheminski, T. Walz, Molecular architecture of the TRAPPII complex and implications for vesicle tethering, Nature Structural \& Molecular Biology. 17 (2010) 1298-1304. https://doi.org/10.1038/nsmb.1914.

[35] S. Jones, C. Newman, F. Liu, N. Segev, The TRAPP Complex Is a Nucleotide Exchanger for Ypt1 and Ypt31/32, MBoC. 11 (2000) 4403-4411. https://doi.org/10.1091/mbc.11.12.4403.

[36] Z. Lipatova, N.V. Bergen, D. Stanga, M. Sacher, J. Christodoulou, N. Segev, TRAPPing a neurological disorder: from yeast to humans, Autophagy. 16 (2020) 965-966. https://doi.org/10.1080/15548627.2020.1736873. 
627 [37] M. Zong, X. Wu, C.W.L. Chan, M.Y. Choi, H.C. Chan, J.A. Tanner, S. Yu, The Adaptor Function of TRAPPC2 in Mammalian TRAPPs Explains TRAPPC2Associated SEDT and TRAPPC9-Associated Congenital Intellectual Disability, PLOS ONE. 6 (2011) e23350. https://doi.org/10.1371/journal.pone.0023350.

[38] S. Brunet, N. Shahrzad, D. Saint-Dic, H. Dutczak, M. Sacher, A trs20 Mutation That Mimics an SEDT-Causing Mutation Blocks Selective and Non-Selective Autophagy: A Model for TRAPP III Organization, Traffic. 14 (2013) 1091-1104. https://doi.org/10.1111/tra.12095.

[39] M.P. Milev, C. Graziano, D. Karall, W.F.E. Kuper, N. Al-Deri, D.M. Cordelli, T.B. Haack, K. Danhauser, A. luso, F. Palombo, T. Pippucci, H. Prokisch, D. Saint-Dic, M. Seri, D. Stanga, G. Cenacchi, K.L.I. van Gassen, J. Zschocke, C. Fauth, J.A. Mayr, M. Sacher, P.M. van Hasselt, Bi-allelic mutations in TRAPPC2L result in a

[40] S. Duerinckx, M. Meuwissen, C. Perazzolo, L. Desmyter, I. Pirson, M. Abramowicz, neurodevelopmental disorder and have an impact on RAB11 in fibroblasts, Journal of Medical Genetics. 55 (2018) 753-764. https://doi.org/10.1136/jmedgenet-2018- 
Clinical Neuromuscular Disease. 19 (2017) 27-30.

https://doi.org/10.1097/CND.0000000000000173.

[42] A.A. Larson, P.R. Baker, M.P. Milev, C.A. Press, R.J. Sokol, M.O. Cox, J.K. Lekostaj, A.A. Stence, A.D. Bossler, J.M. Mueller, K. Prematilake, T.F. Tadjo, C.A. Williams, M. Sacher, S.A. Moore, TRAPPC11 and GOSR2 mutations associate with hypoglycosylation of a-dystroglycan and muscular dystrophy, Skeletal Muscle. 8 (2018) 17. https://doi.org/10.1186/s13395-018-0163-0.

[43] F. Weissmann, G. Petzold, R. VanderLinden, P.J. Huis in 't Veld, N.G. Brown, F. Lampert, S. Westermann, H. Stark, B.A. Schulman, J.-M. Peters, biGBac enables rapid gene assembly for the expression of large multisubunit protein complexes, Proceedings of the National Academy of Sciences. 113 (2016) E2564-E2569. https://doi.org/10.1073/pnas.1604935113.

[44] A. Delprato, E. Merithew, D.G. Lambright, Structure, exchange determinants, and family-wide rab specificity of the tandem helical bundle and Vps9 domains of Rabex-5, Cell. 118 (2004). https://doi.org/10.1016/j.cell.2004.08.009.

[45] J.T.B. Stariha, R.M. Hoffmann, D.J. Hamelin, J.E. Burke, Probing ProteinMembrane Interactions and Dynamics Using Hydrogen-Deuterium Exchange Mass Spectrometry (HDX-MS), Methods Mol Biol. 2263 (2021) 465-485. https://doi.org/10.1007/978-1-0716-1197-5_22.

[46] J.M. Dobbs, M.L. Jenkins, J.E. Burke, Escherichia coli and Sf9 Contaminant Databases to Increase Efficiency of Tandem Mass Spectrometry Peptide 
Identification in Structural Mass Spectrometry Experiments, J Am Soc Mass Spectrom. 31 (2020) 2202-2209. https://doi.org/10.1021/jasms.0c00283.

[47] G.R. Masson, J.E. Burke, N.G. Ahn, G.S. Anand, C. Borchers, S. Brier, G.M. BouAssaf, J.R. Engen, S.W. Englander, J. Faber, R. Garlish, P.R. Griffin, M.L. Gross, M. Guttman, Y. Hamuro, A.J.R. Heck, D. Houde, R.E. lacob, T.J.D. Jørgensen, I.A. Kaltashov, J.P. Klinman, L. Konermann, P. Man, L. Mayne, B.D. Pascal, D. Reichmann, M. Skehel, J. Snijder, T.S. Strutzenberg, E.S. Underbakke, C. Wagner, T.E. Wales, B.T. Walters, D.D. Weis, D.J. Wilson, P.L. Wintrode, Z. Zhang, J. Zheng, D.C. Schriemer, K.D. Rand, Recommendations for performing, interpreting and reporting hydrogen deuterium exchange mass spectrometry (HDXMS) experiments, Nature Methods. 16 (2019) 595-602. https://doi.org/10.1038/s41592-019-0459-y.

[48] Y. Perez-Riverol, A. Csordas, J. Bai, M. Bernal-Llinares, S. Hewapathirana, D.J. Kundu, A. Inuganti, J. Griss, G. Mayer, M. Eisenacher, E. Pérez, J. Uszkoreit, J. Pfeuffer, T. Sachsenberg, Ş. Yılmaz, S. Tiwary, J. Cox, E. Audain, M. Walzer, A.F. Jarnuczak, T. Ternent, A. Brazma, J.A. Vizcaíno, The PRIDE database and related tools and resources in 2019: improving support for quantification data, Nucleic Acids Research. 47 (2019) D442-D450. https://doi.org/10.1093/nar/gky1106.

[49] A. Rohou, N. Grigorieff, CTFFIND4: Fast and accurate defocus estimation from electron micrographs, Journal of Structural Biology. 192 (2015) 216-221. https://doi.org/10.1016/j.jsb.2015.08.008. 
690 [50] New tools for automated high-resolution cryo-EM structure determination in RELION-3 I eLife, (n.d.). https://elifesciences.org/articles/42166 (accessed May 14, 2021).

[51] A. Punjani, J.L. Rubinstein, D.J. Fleet, M.A. Brubaker, cryoSPARC: algorithms for rapid unsupervised cryo-EM structure determination, Nature Methods. 14 (2017)

696 290-296. https://doi.org/10.1038/nmeth.4169.

699 The full length TRAPPII, and Rab genes were used as described previously [10].

700 TRAPPC8, TRAPPC11, and TRAPPC12 genes, were purchased from DNASU (C8-

701 HsCD00347731 \& HsCD00399392, C11- HsCD00082480, C12- HsCD324976) and

702 TRAPPC13 was ordered from Thermofisher Geneart. Genes were subcloned into pLIB

703 vectors, and in the case of TRAPPC12 a TEV cleavable c-term 2x strep tag was added

704 while a TEV cleavable c-term $6 x$ his tag was added to the c-term of TRAPPC11. Genes

705 were subsequently amplified following the biGBac protocol to generate 2 plasmids that

706 together contain all the TRAPPIII genes [43]. A table summarizing the plasmids used is

707 outlined in Table S1.

708 Protein expression

709 All TRAPPII complexes were similarly expressed as previously described [10]. In short,

710 to express TRAPPII/TRAPPIII complexes, an optimized ratio of baculovirus was used to

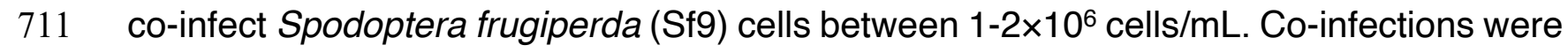


712 harvested at 66 -hours and washed with ice-cold PBS before snap-freezing in liquid

713 nitrogen. Rab constructs were all expressed in BL21 C41 E.coli, induced with 0.5mM

714 IPTG and grown at $37^{\circ} \mathrm{C}$ for $4 \mathrm{hrs}$. Pellets were washed with ice-cold phosphate-buffered

715 saline (PBS), flash frozen in liquid nitrogen, and stored at $-80^{\circ} \mathrm{C}$ until use.

\section{Protein purification}

717 TRAPPII complexe and Rabs were purified as described previously [10]. TRAPP cell

718 pellets were lysed by sonication for 1.5 minutes in lysis buffer (20mM Tris pH 8.0, 100mM

$719 \mathrm{NaCl}, 5 \%(\mathrm{v} / \mathrm{v})$ glycerol, 2mM ß-mercaptoethanol (BME), and protease inhibitors

720 (Millipore Protease Inhibitor Cocktail Set III, Animal-Free)). Triton X-100 was added to

$7210.1 \% \mathrm{v} / \mathrm{v}$, and the solution was centrifuged for 45 minutes at $20,000 \times \mathrm{g}$ at $1^{\circ} \mathrm{C}$. The

722 supernatant was then loaded onto a $5 \mathrm{~mL}$ HisTrap ${ }^{\mathrm{TM}}$ FF column (GE Healthcare) that had

723 been equilibrated in NiNTA A buffer (20 mM Tris pH8.0, 100 mM NaCl, $10 \mathrm{mM}$ imidazole

$724 \mathrm{pH} 8.0,5 \%(\mathrm{v} / \mathrm{v})$ glycerol, $2 \mathrm{mM}$ bME). The column was washed with $20 \mathrm{~mL}$ of NiNTA

725 buffer, $20 \mathrm{~mL}$ of $6 \%$ NiNTA B buffer (20 mM Tris pH 8.0, $100 \mathrm{mM} \mathrm{NaCl}, 200 \mathrm{mM}$ imidazole

$726 \mathrm{pH} 8.0,5 \%(\mathrm{v} / \mathrm{v})$ glycerol, $2 \mathrm{mM}$ bME) before being eluted with $100 \%$ NiNTA B. The eluate

727 was subsequently loaded on a $5 \mathrm{ml}$ Strep $^{\mathrm{TM}}$ column and washed with 10ml SEC buffer

728 (20mM HEPES pH 7.5, 100mM NaCl, 0.5mM TCEP). The Strep-tag was cleaved by

729 adding SEC buffer containing 10mM BME and TEV protease to the column and

730 incubating overnight at $4^{\circ} \mathrm{C}$. Protein was pooled and concentrated using Amicon 50K

731 concentrator and size exclusion chromatography (SEC) was performed using a Superose

7326 increase 10/300 column equilibrated in SEC Buffer. Yield can be improved by taking

733 pooled TRAPP complex before SEC and manually running protein through a $1 \mathrm{~mL}$ 
734 HisTrap ${ }^{\mathrm{TM}}$ FF column (GE Healthcare) that had been equilibrated in NiNTA A buffer

735 followed by buffer exchange into SEC buffer using a $5 \mathrm{~mL}$ HiTrap® Desalting Column

736 (GE Healthcare). Fractions containing protein of interest were pooled, concentrated, flash

737 frozen in liquid nitrogen and stored at $-80^{\circ} \mathrm{C}$.

738 For Rab purification, cell pellets were lysed by sonication for 5 minutes in lysis buffer

739 (20mM Tris pH 8.0, 100mM NaCl, 5\% (v/v) glycerol, 2mM B-mercaptoethanol (BME), and

740 protease inhibitors (Millipore Protease Inhibitor Cocktail Set III, Animal-Free)). Triton X-

741100 was added to $0.1 \% \mathrm{v} / \mathrm{v}$, and the solution was centrifuged for 45 minutes at $20,000 \mathrm{x}$

$742 \mathrm{~g}$ at $1^{\circ} \mathrm{C}$. Supernatant was loaded onto a $5 \mathrm{ml}$ GSTrap 4B column (GE Healthcare) in a

743 superloop for 1.5 hours and the column was washed in Buffer A (20mM Tris pH 8.0,

$744100 \mathrm{mM} \mathrm{NaCl}, 5 \%(\mathrm{v} / \mathrm{v})$ glycerol, $2 \mathrm{mM}$ BME) to remove non-specifically bound proteins.

745 The GST-tag was cleaved by adding Buffer A containing 10mM BME and TEV protease

746 to the column and incubating overnight at $4^{\circ} \mathrm{C}$. Cleaved protein was eluted with Buffer A.

747 Protein was further purified by separating on a $5 \mathrm{ml}$ HiTrap $\mathrm{Q}$ column with a gradient of

748 Buffer A and Buffer B (20mM Tris pH 8.0, 1M NaCl, 5\% (v/v) glycerol, 2mM BME). Protein

749 was pooled and concentrated using an Amicon 30K concentrator, and were flash frozen

750 in liquid nitrogen and stored at $-80^{\circ} \mathrm{C}$.

751 Lipid vesicle preparation

752 Nickelated lipid vesicles were made with 10\% phosphatidylserine (bovine brain PS,

753 Sigma), $\quad 10 \% \quad$ L-a-phosphatidylinositol-4-phosphate $\quad$ (PI4P, Avanti) $\quad 30 \%$

754 phosphatidylcholine (egg yolk PC, Sigma), 10\% L-a-Phosphatidylinositol (Liver PI, 755 Avanti), 15\% L-a-Phosphatidylethanolamine (egg yolk PE, Sigma), and 10\% DGS- 
756 NTA(Ni) (18:1 DGSNTA(Ni), Avanti). Vesicles were prepared by combining liquid

757 chloroform stocks together at appropriate concentrations and evaporating away the

758 chloroform with nitrogen gas. The resulting lipid film layer was desiccated for $20 \mathrm{~min}$

759 before being resuspended in lipid buffer (20mM HEPES $(\mathrm{pH} 7.5)$ and $100 \mathrm{mM} \mathrm{KCl})$ to a

760 concentration of $1 \mathrm{mg} / \mathrm{ml}$. The lipid solution was vortexed for $5 \mathrm{~min}$, bath sonicated for 10

$761 \mathrm{~min}$, and flash frozen in liquid nitrogen. Vesicles were then subjected to three freeze thaw

762 cycles using a warm water bath. Vesicles were extruded 11 times through a 150nm

763 NanoSizer Liposome Extruder (T\&T Scientific) and stored at $-80^{\circ} \mathrm{C}$.

764 In-vitro GEF assay

765 C-terminally His-tagged Rabs were purified, and nucleotide loaded as described

766 previously [10]. Reactions were conducted in $10 \mu$ l volumes with a final concentration of 4

$767 \mu \mathrm{M}$ Mant-GDP loaded Rab, $100 \mu \mathrm{M}$ GTPYS, the appropriate amount of TRAPP $(4.5-300$

$768 \mu \mathrm{M})$ and synthetic vesicles $(0.2 \mathrm{mg} / \mathrm{ml})$. Rab and membrane were aliquoted into a 384-

769 well, black, low-volume plate (Corning 3676). To start the reaction, TRAPP and GTPYS

770 were added simultaneously to the wells and a SpectraMax® M5 Multi-Mode Microplate

771 Reader was used to measure the fluorescent signal for $1 \mathrm{hr}$ (Excitation $\lambda=366 \mathrm{~nm}$;

772 Emission $\lambda=443 \mathrm{~nm}$ ). Data was analyzed using GraphPad Prism 7 Software, and $\mathrm{k}_{\text {cat }} / \mathrm{K}_{\mathrm{m}}$

773 analysis was carried out according to the protocol of [44]. GEF curves were fit to a non-

774 linear dissociate one phase exponential decay using the formula $I(t)=\left(I_{0}-I_{\infty}\right)^{*} \exp \left(-k_{o b s}{ }^{*}\right)+$

$775 \mathrm{I}_{\infty}$ (GraphPad Software), where I(t) is the emission intensity as a function of time, and $\mathrm{I}_{0}$

776 and $\mathrm{I}_{\infty}$ are the emission intensities at $\mathrm{t}=0$ and $\mathrm{t}=\infty$. The catalytic efficiency $\mathrm{k}_{\mathrm{cat}} / \mathrm{K}_{\mathrm{m}}$ was 
777 obtained by a slope of a linear least squares fit to $k_{o b s}=k_{c a t} / K_{m}{ }^{*}[G E F]+k_{i n t r}$, where $k_{\text {intr }}$ is

778 the rate constant in the absence of GEF.

779 Hydrogen deuterium exchange (HDX)

780 TRAPPII vs TRAPPIII

781 HDX reactions comparing both complexes were conducted in $50 \mu \mathrm{l}$ reaction volumes with

782 a final concentration of $160 \mathrm{nM}$ for TRAPPII or TRAPPIII. Exchange was carried out in

783 triplicate for five time points (3s at $4^{\circ} \mathrm{C}$ and $3 \mathrm{~s}, 30 \mathrm{~s}, 300 \mathrm{~s}$ and $3000 \mathrm{~s}$ at $20^{\circ} \mathrm{C}$ ). Hydrogen

784 deuterium exchange was initiated by the addition of $40 \mu$ of $\mathrm{D}_{2} \mathrm{O}$ buffer solution (10mM

785 HEPES pH 7.5, 50mM NaCl, $97 \% \mathrm{D}_{2} \mathrm{O}$ ) to give a final concentration of $78 \% \mathrm{D}_{2} \mathrm{O}$.

786 Exchange was terminated by the addition of acidic quench buffer at a final concentration

$787 \quad 0.6 \mathrm{M}$ guanidine- $\mathrm{HCl}$ and $0.9 \%$ formic acid. Samples were immediately frozen in liquid

788 nitrogen at $-80^{\circ} \mathrm{C}$.

789 Hydrogen deuterium exchange (HDX) TRAPPII and TRAPPIII apo vs Membrane

790 HDX reactions comparing both complexes bound to membranes were conducted in $50 \mu \mathrm{l}$

791 reaction volumes with a final concentration of $120 \mathrm{nM}$ for TRAPPII or TRAPPIII and

$7920.1 \mathrm{mg} / \mathrm{ml}$ membranes. Exchange was carried out in triplicate for three time points (3s,

$793100 \mathrm{~s}$ and $3000 \mathrm{~s}$ at $20^{\circ} \mathrm{C}$ ). Prior to the addition of $\mathrm{D}_{2} \mathrm{O}$, TRAPP was incubated at $20^{\circ} \mathrm{C}$

794 with vesicles for one minute to facilitate TRAPP-membrane interactions. Hydrogen

795 deuterium exchange was initiated by the addition of $32.1 \mu \mathrm{l}$ of $\mathrm{D}_{2} \mathrm{O}$ buffer solution (10mM

$796 \mathrm{HEPES} \mathrm{pH} 7.5,50 \mathrm{mM} \mathrm{NaCl}, 97 \% \mathrm{D}_{2} \mathrm{O}$ ) to the protein/membrane solutions, to give a final

797 concentration of $62 \% \mathrm{D}_{2} \mathrm{O}$. Exchange was terminated by the addition of acidic quench 
798 buffer at a final concentration $0.6 \mathrm{M}$ guanidine- $\mathrm{HCl}$ and $0.9 \%$ formic acid. Samples were

799 immediately frozen in liquid nitrogen at $-80^{\circ} \mathrm{C}$.

Hydrogen deuterium exchange (HDX) TRAPPIII apo vs Rab bound

801 HDX reactions comparing TRAPPIII and TRAPPIII-Rab1 complex were conducted in 50 $\mu$ I

802 reaction volumes with a final concentration 100nM TRAPPIII per sample and $560 \mathrm{nM}$

803 Rab1. Exchange was carried out in triplicate for four time points (3s, 30s, 300s and 3000s

804 at $20^{\circ} \mathrm{C}$ ). Prior to the addition of $\mathrm{D}_{2} \mathrm{O}$, proteins were incubated on ice in the presence of

$80520 \mathrm{mM}$ EDTA for 30 minutes to facilitate release of nucleotide. Hydrogen deuterium

806 exchange was initiated by the addition of $43.1 \mu$ of $\mathrm{D}_{2} \mathrm{O}$ buffer solution (10mM HEPES pH

$\left.8077.5,50 \mathrm{mM} \mathrm{NaCl}, 97 \% \mathrm{D}_{2} \mathrm{O}\right)$ to give a final concentration of $82 \% \mathrm{D}_{2} \mathrm{O}$. Exchange was

808 terminated by the addition of acidic quench buffer at a final concentration 0.6M guanidine-

$809 \mathrm{HCl}$ and $0.9 \%$ formic acid. Samples were immediately frozen in liquid nitrogen at $-80^{\circ} \mathrm{C}$.

\section{HDX-MS data Analysis}

811 Protein samples were rapidly thawed and injected onto an integrated fluidics system

812 containing a HDx-3 PAL liquid handling robot and climate-controlled $\left(2^{\circ} \mathrm{C}\right)$

813 chromatography system (LEAP Technologies), a Dionex Ultimate 3000 UHPLC system,

814 as well as an Impact HD QTOF Mass spectrometer (Bruker) [45]. The protein was run

815 over one (at $10^{\circ} \mathrm{C}$ ) immobilized pepsin column (Trajan; ProDx protease column, $2.1 \mathrm{~mm}$

816 x $30 \mathrm{~mm}$ PDX.PP01-F32) at $200 \mu \mathrm{L} / \mathrm{min}$ for 3 minutes. The resulting peptides were

817 collected and desalted on a C18 trap column (Acquity UPLC BEH C18 1.7mm column

818 (2.1 x $5 \mathrm{~mm})$; Waters 186003975). The trap was subsequently eluted in line with an

819 ACQUITY $1.7 \mu \mathrm{m}$ particle, $100 \times 1 \mathrm{~mm} 2$ C18 UPLC column (Waters), using a gradient of 
820 3-35\% B (Buffer A 0.1\% formic acid; Buffer B 100\% acetonitrile) over 11 minutes

821 immediately followed by a gradient of $35-80 \%$ over 5 minutes. Mass spectrometry

822 experiments acquired over a mass range from 150 to $2200 \mathrm{~m} / \mathrm{z}$ using an electrospray

823 ionization source operated at a temperature of $200 \mathrm{C}$ and a spray voltage of $4.5 \mathrm{kV}$. The

824 resulting MS/MS datasets were analyzed using PEAKS7 (PEAKS), and a false discovery

825 rate was set at $1 \%$ using a database of purified proteins and known contaminants [46].

826 HDExaminer Software (Sierra Analytics) was used to automatically calculate the level of

827 deuterium incorporation into each peptide. All peptides were manually inspected for

828 correct charge state and presence of overlapping peptides. Deuteration levels were

829 calculated using the centroid of the experimental isotope clusters. Differences in

830 exchange were in a peptide were considered significant if they met all three of the

831 following criteria: $>5 \%$ change in exchange, $>0.5$ Da difference in exchange, and a $p$

832 value $<0.01$ using a two tailed student t-test. Samples were only compared within a single

833 experiment and were never compared to experiments completed at a different time with

834 a different final $\mathrm{D}_{2} \mathrm{O}$ level.

The data analysis statistics for all HDX-MS experiments are in supplemental tables

$8362-4$ according to the guidelines of [47]. The mass spectrometry proteomics data have

837 been deposited to the ProteomeXchange Consortium via the PRIDE partner repository

838 [48] with the dataset identifier PXD025928.

839 Negative stain single-particle electron microscopy (EM) and image analysis

$840 \quad$ Purified TRAPPIII complex was adsorbed to glow discharged carbon coated grids

841 and stained with uranyl formate. The stained specimens were examined using a Talos 
842 L120C transmission electron microscope (ThermoFisher Scientific) operated at an

843 accelerating voltage of $120 \mathrm{kV}$ and equipped with a Ceta charged-coupled-device (CCD)

844 camera. 100 micrographs were acquired at a nominal magnification of $45,000 x$ at a

845 defocus of $\sim 1.2 \mu \mathrm{m}$ and binned twice to obtain a final pixel size of $4.53 \AA$ pixel. Contrast

846 transfer function (CTF) estimation for each micrograph was carried out using CTFFind4

847 [49]. 200 particles were manually picked then aligned to generate 2D class averages for

848 template-based autopicking in Relion 3.0 [50]. 38,062 particles were autopicked and

849 extracted with a box size of 148 pixels. Particles were then subjected to 2D classification

850 and 1034 particles which did not classify well were discarded. The remaining particles

851 were transferred to cryoSPARC v2.14 [51] for ab initio reconstruction using 2 classes

852 which were refined by heterogenous refinement. A final particle stack of 32,429 particles

853 was used to carry out homogenous refinement of the better model, yielding a final map

854 at $14.2 \AA$ resolution based on the gold-standard 0.143 Fourier Shell Correlation criterion

855 (Fig. S1). The EM data have been deposited to the EMDB with the accession code: EMD-

85623997. 


\section{Supplemental Information for}

\section{Biochemical insight into novel Rab-GEF activity of the}

\section{mammalian TRAPPIII complex}

Noah J Harris ${ }^{1}$, Meredith L Jenkins ${ }^{1}$, Udit Dalwadi², Kaelin D Fleming ${ }^{1}$, Sung-Eun-Nam², Matthew AH Parsons ${ }^{1}$, Calvin K Yip ${ }^{2}$, John E Burke ${ }^{1,2 \%}$

${ }^{1}$ Department of Biochemistry and Microbiology, University of Victoria, Victoria, British Columbia, Canada V8W 2Y2

${ }^{2}$ Life Sciences Institute, Department of Biochemistry and Molecular Biology, The University of British Columbia, Vancouver, British Columbia V6T 1Z3, Canada

\%To whom correspondence should be addressed: John E. Burke Tel: 1-250-721-8732, email: jeburke@uvic.ca 
A

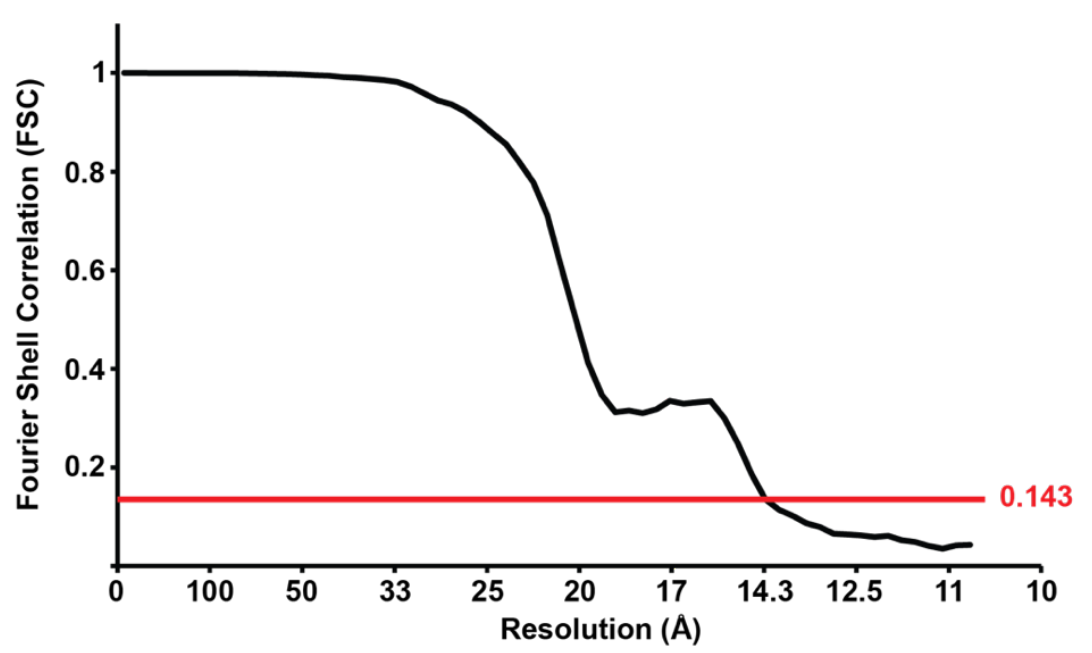

B

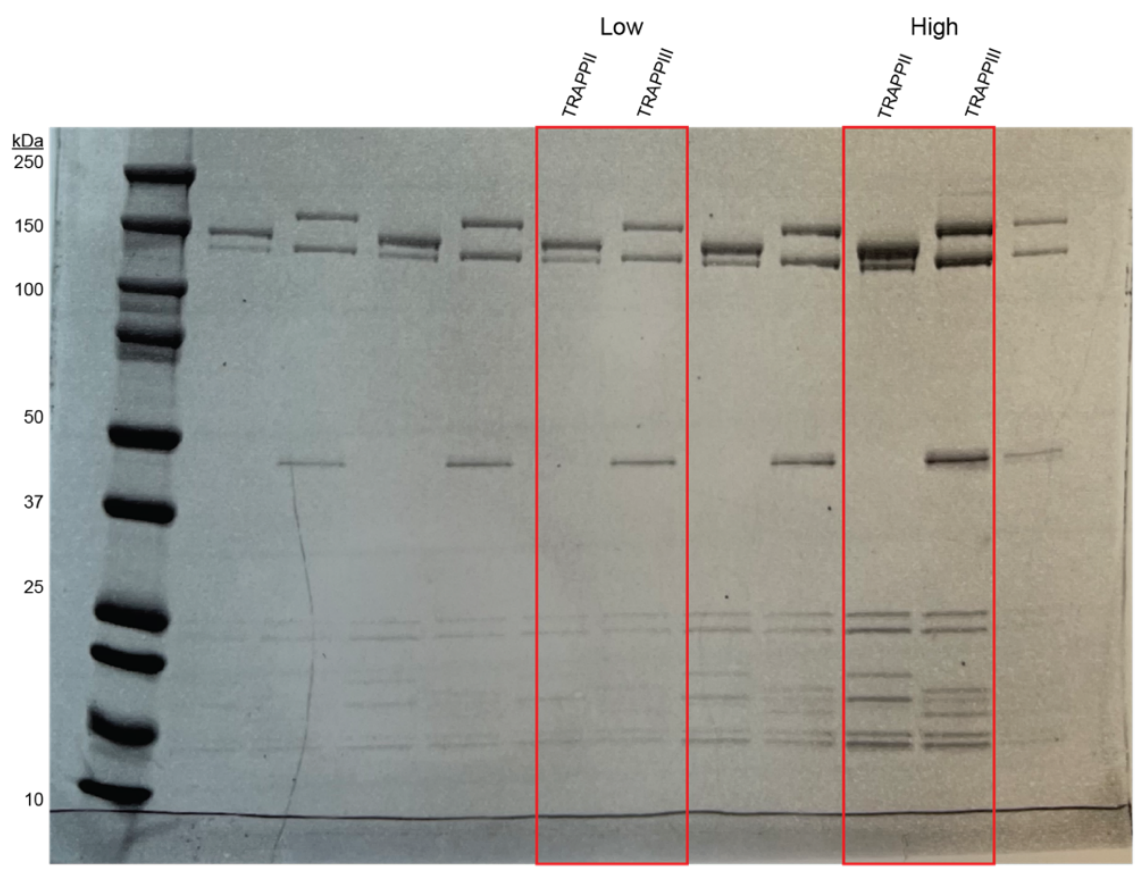

Supplemental Figure 1. Gold-standard Fourier shell correlation and SDS-PAGE gel of purified TRAPP complexes.

(A) Gold-standard Fourier shell correlation curve showing the resolution of the TRAPPIII model in figure 1.

(B) Uncropped SDS-PAGE gel of TRAPPII and TRAPPIII used in figure 1. High and low refer to protein amount loaded (high=3.6ug and low=1.4ug). 4-20\% NuPAGE gradient gel run at $225 \mathrm{~V}$ for $35 \mathrm{~min}$ and stained with Coomassie Brilliant Blue dye. 


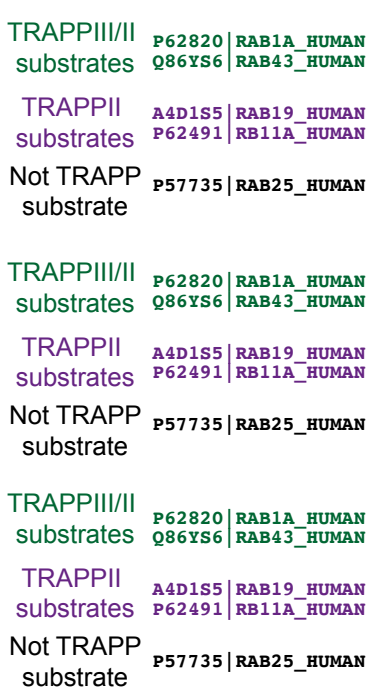

\section{Supplemental Figure 2. Alignment of substrate Rabs for mammalian TRAPP}

\section{complexes.}

Alignment of Rab1, Rab43, Rab19, Rab11a, and Rab25. Putative contact sites with the TRAPP core are based on the pdb: 3CUE. Alignment was generated using Espript [1]. 
bioRxiv preprint doi: https://doi.org/10.1101/2021.06.01.446621; this version posted June 1, 2021. The copyright holder for this preprint (which was not certified by peer review) is the author/funder, who has granted bioRxiv a license to display the preprint in perpetuity. It is made available under aCC-BY-NC-ND 4.0 International license.

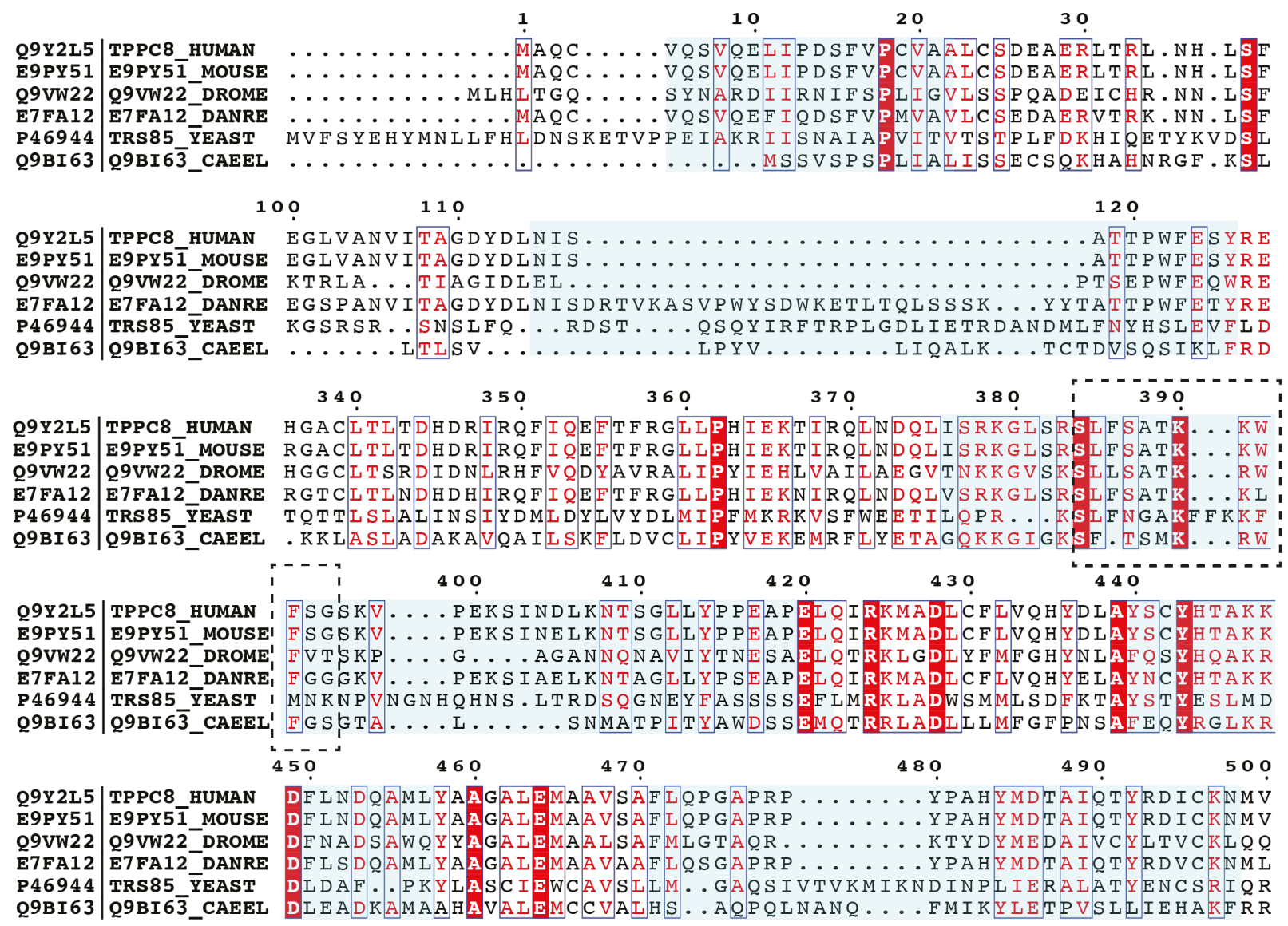

Decreases in exchange with membranes

\section{Supplemental Figure 3. Alignment of TRAPPC8}

Decreases in exchange upon membrane binding are highlighted in light blue. The putative amphipathic helix from Trs85 is indicated in the boxed dotted line. Alignment was generated using Espript [1] 
bioRxiv preprint doi: https://doi.org/10.1101/2021.06.01.446621; this version posted June 1, 2021. The copyright holder for this preprint (which was not certified by peer review) is the author/funder, who has granted bioRxiv a license to display the preprint in perpetuity. It is made available under aCC-BY-NC-ND 4.0 International license.

Supplemental table 1. All plasmids used in this study.

\begin{tabular}{|c|c|c|c|c|c|}
\hline Name & Plasmid & Protein(s) & Sequence(s) & Modifications/Tags & Source \\
\hline $\begin{array}{c}\text { MJ153 } \\
\text { [TRAPPIla] }\end{array}$ & pBIG1a & $\begin{array}{l}\text { TRAPPC1; } \\
\text { TRAPPC2L; } \\
\text { TRAPPC5; } \\
\text { TRAPPC6a; } \\
\text { TRAPPC10; }\end{array}$ & $\begin{array}{l}1-145 \\
1-140 \\
1-188 \\
1-173 \\
1-1259\end{array}$ & TRAPPC10 - C-term His Tag (TEV) & [2] \\
\hline $\begin{array}{c}\text { MJ85 } \\
\text { [TRAPPIIb] }\end{array}$ & pBIG1a & $\begin{array}{l}\text { TRAPPC3; } \\
\text { TRAPPC2; } \\
\text { TRAPPC4; } \\
\text { TRAPPC9 }\end{array}$ & $\begin{array}{l}1-180 ; \\
1-140 \\
1-235 \\
1-1148 \\
\end{array}$ & TRAPPC3 - C-term Strep Tag (TEV) & [2] \\
\hline $\begin{array}{c}\mathrm{NH} 40 \\
\text { [TRAPPIIIa] }\end{array}$ & pBIG1a & $\begin{array}{l}\text { TRAPPC8; } \\
\text { TRAPPC11; } \\
\text { TRAPPC12; } \\
\text { TRAPPC13 }\end{array}$ & $\begin{array}{c}1-1435 \\
1-1147 \\
300-735 \\
1-417\end{array}$ & $\begin{array}{l}\text { TRAPPC12 - C-term Strep Tag (TEV); } \\
\text { TRAPPC11 - C-term His Tag (TEV) }\end{array}$ & This paper \\
\hline $\begin{array}{c}\mathrm{NH42} \\
\text { [TRAPPIIIb] }\end{array}$ & pBIG2ab & $\begin{array}{l}\text { TRAPPC1; } \\
\text { TRAPPC2; } \\
\text { TRAPPC2L; } \\
\text { TRAPPC3; } \\
\text { TRAPPC4; } \\
\text { TRAPPC5; } \\
\text { TRAPPC6a }\end{array}$ & $\begin{array}{l}1-145 ; \\
1-140 ; \\
1-140 \\
1-180 \\
1-235 \\
1-188 \\
1-173\end{array}$ & & This paper \\
\hline MJ117 & pOPTGcH & Rab1a & $1-203$ & N-term GST Tag(TEV); C-term His Tag & [2] \\
\hline MJ37 & pOPTGcH & Rab2a & $1-210$ & N-term GST Tag(TEV); C-term His Tag & [2] \\
\hline EM11 & pOPTGcH & Rab3a & $1-217$ & N-term GST Tag(TEV); C-term His Tag & [2] \\
\hline MJ36 & pOPTGcH & Rab4b & $1-210$ & N-term GST Tag(TEV); C-term His Tag & [2] \\
\hline $\mathrm{DH} 1$ & pOPTGcH & Rab5a & $1-212$ & N-term GST Tag(TEV); Q79L mutation & [2] \\
\hline EM13 & pOPTGcH & Rab6a & $1-205$ & N-term GST Tag(TEV); C-term His Tag & [2] \\
\hline $\mathrm{NH} 20$ & pOPTGcH & Rab7a & $1-204$ & N-term GST Tag(TEV); C-term His Tag & [2] \\
\hline MJ40 & pOPTGcH & Rab8a & $1-203$ & N-term GST Tag(TEV); C-term His Tag & [2] \\
\hline EO7 & pOPTGcH & Rab11a & $1-211$ & N-term GST Tag(TEV); C-term His Tag & [2] \\
\hline MJ28 & pOPTGcH & Rab11b & $1-213$ & N-term GST Tag(TEV); C-term His Tag & [2] \\
\hline MJ39 & pOPTGcH & Rab12 & $1-242$ & N-term GST Tag(TEV); C-term His Tag & [2] \\
\hline MJ38 & pOPTGcH & Rab14 & $1-212$ & N-term GST Tag(TEV); C-term His Tag & [2] \\
\hline EM15 & pOPTGcH & Rab18 & $1-198$ & N-term GST Tag(TEV); C-term His Tag & [2] \\
\hline MJ167 & pOPTGcH & Rab19 & $1-214$ & N-term GST Tag(TEV); C-term His Tag & [2] \\
\hline MJ27 & pOPTGcH & Rab25 & $1-208$ & N-term GST Tag(TEV); C-term His Tag & [2] \\
\hline $\mathrm{NH} 19$ & pOPTGcH & Rab29 & $1-201$ & N-term GST Tag(TEV); C-term His Tag & [2] \\
\hline $\mathrm{NH} 21$ & pOPTGcH & Rab32 & $1-223$ & N-term GST Tag(TEV); C-term His Tag & [2] \\
\hline EM17 & pOPTGcH & Rab33a & $1-234$ & N-term GST Tag(TEV); C-term His Tag & [2] \\
\hline Em19 & pOPTGcH & Rab35 & $1-199$ & N-term GST Tag(TEV); C-term His Tag & [2] \\
\hline EM23 & pOPTGcH & Rab39a & $1-214$ & N-term GST Tag(TEV); C-term His Tag & [2] \\
\hline EM25 & pOPTGcH & Rab43 & $1-209$ & N-term GST Tag(TEV); C-term His Tag & [2] \\
\hline MJ210 & pOPTGcH & Rab11A chimera 1 & $1-209$ & $\begin{array}{l}\text { N-term GST Tag(TEV); C-term His Tag; } \\
\text { Rab11 tail swapped with Rab1 tail }\end{array}$ & This paper \\
\hline MJ211 & pOPTGcH & Rab1A chimera 1 & $1-217$ & $\begin{array}{l}\text { N-term GST Tag(TEV); C-term His Tag; } \\
\text { Rab1a tail swapped with Rab11a tail }\end{array}$ & This paper \\
\hline MJ201 & pOPTGcH & Rab11A chimera 2 & $1-209$ & $\begin{array}{l}\text { N-term GST Tag(TEV); C-term His Tag; } \\
\text { Rab11a tail swapped with Rab1 tail }\end{array}$ & This paper \\
\hline MJ202 & pOPTGcH & Rab1A chimera 2 & $1-217$ & $\begin{array}{l}\text { N-term GST Tag(TEV); C-term His Tag; } \\
\text { Rab1a tail swapped with Rab11 tail }\end{array}$ & This paper \\
\hline
\end{tabular}


bioRxiv preprint doi: https://doi.org/10.1101/2021.06.01.446621; this version posted June 1, 2021. The copyright holder for this preprint (which was not certified by peer review) is the author/funder, who has granted bioRxiv a license to display the preprint in perpetuity. It is made available under aCC-BY-NC-ND 4.0 International license.

Supplemental Table 2. HDX Statistics for Figure 3 - TRAPPIII Rab

\begin{tabular}{|c|c|c|c|c|c|c|}
\hline Data set & TRAPP C1 & TRAPP C2 & TRAPP C2L & TRAPP C3 & TRAPP C4 & TRAPP C5 \\
\hline $\begin{array}{l}\text { HDX } \\
\text { reaction } \\
\text { details } \\
\end{array}$ & $\begin{array}{l}\% \mathrm{D}_{2} \mathrm{O}=82 \% \\
\mathrm{pH}_{\text {raan }}=7.5 \\
\mathrm{Temp}=20^{\circ} \mathrm{C}\end{array}$ & $\begin{array}{l}\% \mathrm{D}_{2} \mathrm{O}=82 \% \\
\mathrm{pH}_{\text {max }}=7.5 \\
\mathrm{Temp}=20^{\circ} \mathrm{C}\end{array}$ & $\begin{array}{l}\% \mathrm{D}_{2} \mathrm{O}=82 \% \\
\mathrm{pH}_{\text {max }}=7.5 \\
\mathrm{Temp}=20^{\circ} \mathrm{C}\end{array}$ & $\begin{array}{l}\% \mathrm{D}_{2} \mathrm{O}=82 \% \\
\mathrm{pH}_{\text {rous }}=7.5 \\
\mathrm{Temp}=20^{\circ} \mathrm{C}\end{array}$ & $\begin{array}{l}\% \mathrm{D}_{2} \mathrm{O}=82 \% \\
\mathrm{pH}_{\text {mos }}=7.5 \\
\mathrm{Temp}=20^{\circ} \mathrm{C}\end{array}$ & $\begin{array}{l}\% \mathrm{D}_{2} \mathrm{O}=82 \% \\
\mathrm{pH}_{\text {rax }}=7.5 \\
\mathrm{Temp}=20^{\circ} \mathrm{C}\end{array}$ \\
\hline $\begin{array}{l}\text { HDX time } \\
\text { course (s) }\end{array}$ & $\begin{array}{l}3,30,300 \\
3000\end{array}$ & $\begin{array}{l}3,30,300 \\
3000\end{array}$ & $3,30,300,3000$ & $3,30,300,3000$ & $\begin{array}{l}3,30,300 \\
3000\end{array}$ & $3,30,300,3000$ \\
\hline $\begin{array}{l}\text { HDX } \\
\text { controls }\end{array}$ & N/A & N/A & $\mathrm{N} / \mathrm{A}$ & $\mathrm{N} / \mathrm{A}$ & $\mathrm{N} / \mathrm{A}$ & $\mathrm{N} / \mathrm{A}$ \\
\hline $\begin{array}{l}\text { Back- } \\
\text { exchange }\end{array}$ & $\begin{array}{l}\text { Corrected } \\
\text { based on } \\
\% \mathrm{D}_{2} \mathrm{O}\end{array}$ & $\begin{array}{l}\text { Corrected } \\
\text { based on } \\
\% \mathrm{D}_{2} \mathrm{O}\end{array}$ & $\begin{array}{l}\text { Corrected based } \\
\text { on } \% \mathrm{D}=\end{array}$ & $\begin{array}{l}\text { Corrected based } \\
\text { on } \% \mathrm{D}, \mathrm{O}\end{array}$ & $\begin{array}{l}\text { Corrected } \\
\text { based on } \\
\% \mathrm{DO}\end{array}$ & $\begin{array}{l}\text { Corrected based } \\
\text { on } \% \mathrm{D}=\end{array}$ \\
\hline $\begin{array}{l}\text { Number of } \\
\text { peptides }\end{array}$ & 18 & 25 & 22 & 24 & 29 & 23 \\
\hline $\begin{array}{l}\text { Sequence } \\
\text { coverage }\end{array}$ & 97.2 & 87.1 & 90.7 & 58.3 & 96.3 & 87.2 \\
\hline $\begin{array}{l}\text { Average } \\
\text { peptide } \\
\text { /redundancy }\end{array}$ & $\begin{array}{l}\text { Length }=11.9 \\
\text { Redundancy= } \\
1.5\end{array}$ & $\begin{array}{l}\text { Length }=13.3 \\
\text { Redundancy= } \\
2.4\end{array}$ & $\begin{array}{l}\text { Length }=11.9 \\
\text { Redundancy }=1.9\end{array}$ & $\begin{array}{l}\text { Length }=10.6 \\
\text { Redundancy }=1.4\end{array}$ & $\begin{array}{l}\text { Length }=12.2 \\
\text { Redundancy= } \\
1.6\end{array}$ & $\begin{array}{l}\text { Length }=13 \\
\text { Redundancy= } \\
1.6\end{array}$ \\
\hline Replicates & 3 & 3 & 3 & 3 & 3 & 3 \\
\hline Repeatability & $\begin{array}{l}\text { Average } \\
\text { StDev }=0.9 \%\end{array}$ & $\begin{array}{l}\text { Average } \\
\text { StDev }=0.7 \%\end{array}$ & $\begin{array}{l}\text { Average } \\
\text { StDev }=1.4 \%\end{array}$ & $\begin{array}{l}\text { Average } \\
\text { StDev=1.1\% }\end{array}$ & $\begin{array}{l}\text { Average } \\
\text { StDev=1\% }\end{array}$ & $\begin{array}{l}\text { Average } \\
\text { StDev }=1.1 \%\end{array}$ \\
\hline $\begin{array}{l}\text { Significant } \\
\text { differences } \\
\text { in HDX }\end{array}$ & $\begin{array}{l}>5 \% \text { and } \\
>0.5 \mathrm{Da} \text { and } \\
\text { unpaired t- } \\
\text { test } \leq 0.01\end{array}$ & $\begin{array}{l}>5 \% \text { and } \\
>0.5 \mathrm{Da} \text { and } \\
\text { unpaired t- } \\
\text { test } \leq 0.01\end{array}$ & $\begin{array}{l}>5 \% \text { and }>0.5 \mathrm{Da} \\
\text { and unpaired t- } \\
\text { test } \leq 0.01\end{array}$ & $\begin{array}{l}>5 \% \text { and }>0.5 \mathrm{Da} \\
\text { and unpaired t- } \\
\text { test } \leq 0.01\end{array}$ & $\begin{array}{l}>5 \% \text { and } \\
>0.5 \mathrm{Da} \text { and } \\
\text { unpaired } \mathrm{t}- \\
\text { test } \leq 0.01\end{array}$ & $\begin{array}{l}>5 \% \text { and }>0.5 \mathrm{Da} \\
\text { and unpaired t- } \\
\text { test } \leq 0.01\end{array}$ \\
\hline Data set & TRAPP C6 & TRAPP C8 & TRAPP C11 & TRAPP C12 & TRAPP C13 & Rab1a \\
\hline $\begin{array}{l}\text { HDX } \\
\text { reaction } \\
\text { details }\end{array}$ & $\begin{array}{l}\% \mathrm{D}_{2} \mathrm{O}=82 \% \\
\mathrm{pH}_{\text {tran }}=7.5 \\
\mathrm{Temp}=20^{\circ} \mathrm{C}\end{array}$ & $\begin{array}{l}\% \mathrm{D}_{2} \mathrm{O}=82 \% \\
\mathrm{pH}_{\text {rasu }}=7.5 \\
\mathrm{Temp}=20^{\circ} \mathrm{C}\end{array}$ & $\begin{array}{l}\% \mathrm{D}_{2} \mathrm{O}=82 \% \\
\mathrm{pH}_{\text {tean }}=7.5 \\
\mathrm{Temp}=20^{\circ} \mathrm{C}\end{array}$ & $\begin{array}{l}\% \mathrm{D}_{2} \mathrm{O}=82 \% \\
\mathrm{pH}_{\text {max }}=7.5 \\
\mathrm{Temp}=20^{\circ} \mathrm{C}\end{array}$ & $\begin{array}{l}\% \mathrm{D}_{2} \mathrm{O}=82 \% \\
\mathrm{pH}_{\text {mex }}=7.5 \\
\mathrm{Temp}=20^{\circ} \mathrm{C}\end{array}$ & $\begin{array}{l}\% \mathrm{D}_{2} \mathrm{O}=82 \% \\
\mathrm{pH}_{\text {reas }}=7.5 \\
\mathrm{Temp}=20^{\circ} \mathrm{C}\end{array}$ \\
\hline $\begin{array}{l}\text { HDX time } \\
\text { course } \\
\text { (seconds) }\end{array}$ & $\begin{array}{l}3,30,300 \\
3000\end{array}$ & $\begin{array}{l}3,30,300 \\
3000\end{array}$ & $3,30,300,3000$ & $3,30,300,3000$ & $\begin{array}{l}3,30,300 \\
3000\end{array}$ & $3,30,300,3000$ \\
\hline $\begin{array}{l}\mathrm{HDX} \\
\text { controls }\end{array}$ & $\mathrm{N} / \mathrm{A}$ & $\mathrm{N} / \mathrm{A}$ & $\mathrm{N} / \mathrm{A}$ & $\mathrm{N} / \mathrm{A}$ & $\mathrm{N} / \mathrm{A}$ & N/A \\
\hline $\begin{array}{l}\text { Back- } \\
\text { exchange }\end{array}$ & $\begin{array}{l}\text { Corrected } \\
\text { based on } \\
\% \mathrm{D} \text {. }\end{array}$ & $\begin{array}{l}\text { Corrected } \\
\text { based on } \\
\% \mathrm{D}_{2} \mathrm{O}\end{array}$ & $\begin{array}{l}\text { Corrected based } \\
\text { on } \% \mathrm{D}: \mathrm{O}\end{array}$ & $\begin{array}{l}\text { Corrected based } \\
\text { on } \% \mathrm{D} O\end{array}$ & $\begin{array}{l}\text { Corrected } \\
\text { based on } \\
\% \mathrm{D}_{2} \mathrm{O}\end{array}$ & $\begin{array}{l}\text { Corrected based } \\
\text { on } \% \mathrm{D} \mathrm{O}\end{array}$ \\
\hline $\begin{array}{l}\text { Number of } \\
\text { peptides }\end{array}$ & 21 & 157 & 126 & 50 & 84 & 41 \\
\hline $\begin{array}{l}\text { Sequence } \\
\text { coverage }\end{array}$ & 73.4 & 89 & 77.2 & 82.7 & 95.7 & 87.3 \\
\hline $\begin{array}{l}\text { Average } \\
\text { peptide } \\
\text { /redundancy }\end{array}$ & $\begin{array}{l}\text { Length=9.2 } \\
\text { Redundancy= } \\
1.1\end{array}$ & $\begin{array}{l}\text { Length=15.1 } \\
\text { Redundancy= } \\
1.7\end{array}$ & $\begin{array}{l}\text { Length }=12.4 \\
\text { Redundancy }=1.4\end{array}$ & $\begin{array}{l}\text { Length }=13.7 \\
\text { Redundancy }=1.6\end{array}$ & $\begin{array}{l}\text { Length }=11.2 \\
\text { Redundancy= } \\
2.2\end{array}$ & $\begin{array}{l}\text { Length }=14 \\
\text { Redundancy }=2.8\end{array}$ \\
\hline Replicates & 3 & 3 & 3 & 3 & 3 & 3 \\
\hline Repeatability & $\begin{array}{l}\text { Average } \\
\text { StDev }=1.4 \%\end{array}$ & $\begin{array}{l}\text { Average } \\
\text { StDev }=0.9 \%\end{array}$ & $\begin{array}{l}\text { Average } \\
\text { StDev }=0.9 \%\end{array}$ & $\begin{array}{l}\text { Average } \\
\text { StDev }=0.9 \%\end{array}$ & $\begin{array}{l}\text { Average } \\
\text { StDev }=0.9 \%\end{array}$ & $\begin{array}{l}\text { Average } \\
\text { StDev }=0.9 \%\end{array}$ \\
\hline $\begin{array}{l}\text { Significant } \\
\text { differences } \\
\text { in HDX }\end{array}$ & $\begin{array}{l}>5 \% \text { and } \\
>0.5 \mathrm{Da} \text { and } \\
\text { unpaired t- } \\
\text { test } \leq 0.01\end{array}$ & $\begin{array}{l}>5 \% \text { and } \\
>0.5 \mathrm{Da} \text { and } \\
\text { unpaired t- } \\
\text { test } \leq 0.01\end{array}$ & $\begin{array}{l}>5 \% \text { and }>0.5 \mathrm{Da} \\
\text { and unpaired } t- \\
\text { test } \leq 0.01\end{array}$ & $\begin{array}{l}>5 \% \text { and }>0.5 \mathrm{Da} \\
\text { and unpaired t- } \\
\text { test } \leq 0.01\end{array}$ & $\begin{array}{l}>5 \% \text { and } \\
>0.5 \mathrm{Da} \text { and } \\
\text { unpaired t- } \\
\text { test } \leq 0.01\end{array}$ & $\begin{array}{l}>5 \% \text { and }>0.5 \mathrm{Da} \\
\text { and unpaired } \mathrm{t}- \\
\text { test } \leq 0.01\end{array}$ \\
\hline
\end{tabular}


bioRxiv preprint doi: https://doi.org/10.1101/2021.06.01.446621; this version posted June 1, 2021. The copyright holder for this preprint (which was not certified by peer review) is the author/funder, who has granted bioRxiv a license to display the preprint in perpetuity. It is made available under aCC-BY-NC-ND 4.0 International license.

\begin{tabular}{|c|c|c|c|c|c|c|c|}
\hline Data set & TRAPP C1 & TRAPP C2 & TRAPP C2L & TRAPP C3 & TRAPP C4 & TRAPP C5 & TRAPP C6 \\
\hline $\begin{array}{l}\text { HDX } \\
\text { reaction } \\
\text { details }\end{array}$ & $\begin{array}{l}\% \mathrm{DO}=78 \% \\
\mathrm{pH}_{\text {nos }}=7.5 \\
\text { Temp }=4-20^{\circ} \mathrm{C}\end{array}$ & $\begin{array}{l}\% \mathrm{DO}=78 \% \\
\mathrm{pH}_{m=\mathrm{m}}=7.5 \\
\mathrm{Temp}=4-20^{\circ} \mathrm{C}\end{array}$ & $\begin{array}{l}\% \mathrm{D}_{2} \mathrm{O}=78 \% \\
\mathrm{pH}_{\text {som }}=7.5 \\
\mathrm{Temp}^{2}=4- \\
20^{\circ} \mathrm{C}\end{array}$ & $\begin{array}{l}\% \mathrm{D}_{2} \mathrm{O}=78 \% \\
\mathrm{pH}_{\text {tex }}=7.5 \\
\mathrm{Temp}=4- \\
20^{\circ} \mathrm{C}\end{array}$ & $\begin{array}{l}\% \mathrm{D}_{2} \mathrm{O}=78 \% \\
\mathrm{pH}_{\text {mosu }}=7.5 \\
\mathrm{Temp}=4- \\
20^{\circ} \mathrm{C}\end{array}$ & $\begin{array}{l}\% \mathrm{D}_{2} \mathrm{O}=78 \% \\
\mathrm{pH}_{\text {soum }}=7.5 \\
\mathrm{Temp}=4- \\
20^{\circ} \mathrm{C}\end{array}$ & $\begin{array}{l}\% \mathrm{D}_{2} \mathrm{O}=78 \% \\
\mathrm{pH}_{\text {mos }}=7.5 \\
\mathrm{Temp}^{2}=4- \\
20^{\circ} \mathrm{C}\end{array}$ \\
\hline $\begin{array}{l}\text { HDX time } \\
\text { course (s) }\end{array}$ & $\begin{array}{l}3 \text { at } 4^{\circ} \mathrm{C} \\
3,30,300, \\
3000 \text { at } 20^{\circ} \mathrm{C}\end{array}$ & $\begin{array}{l}3 \text { at } 4^{\circ} \mathrm{C} \\
3,30,300, \\
3000 \text { at } 20^{\circ} \mathrm{C}\end{array}$ & $\begin{array}{l}3 \text { at } 4^{\circ} \mathrm{C} \\
3,30,300, \\
3000 \text { at } \\
20^{\circ} \mathrm{C}\end{array}$ & $\begin{array}{l}3 \text { at } 4^{\circ} \mathrm{C} \\
3,30,300, \\
3000 \text { at } \\
20^{\circ} \mathrm{C}\end{array}$ & $\begin{array}{l}3 \text { at } 4^{\circ} \mathrm{C} \\
3,30,300 \text {, } \\
3000 \text { at } \\
20^{\circ} \mathrm{C}\end{array}$ & $\begin{array}{l}3 \text { at } 4^{\circ} \mathrm{C} \\
3,30,300 \text {, } \\
3000 \text { at } \\
20^{\circ} \mathrm{C}\end{array}$ & $\begin{array}{l}3 \text { at } 4^{\circ} \mathrm{C} \\
3,30,300 \text {, } \\
3000 \text { at } \\
20^{\circ} \mathrm{C}\end{array}$ \\
\hline $\begin{array}{l}\text { HDX } \\
\text { controls }\end{array}$ & $\mathrm{N} / \mathrm{A}$ & $\mathrm{N} / \mathrm{A}$ & $\mathrm{N} / \mathrm{A}$ & $\mathrm{N} / \mathrm{A}$ & $\mathrm{N} / \mathrm{A}$ & $\mathrm{N} / \mathrm{A}$ & $\mathrm{N} / \mathrm{A}$ \\
\hline $\begin{array}{l}\text { Back- } \\
\text { exchange }\end{array}$ & $\begin{array}{l}\text { Corrected } \\
\text { based on \% } \\
\text { D.O }\end{array}$ & $\begin{array}{l}\text { Corrected } \\
\text { based on \%D:O }\end{array}$ & $\begin{array}{l}\text { Corrected } \\
\text { based on } \\
\% \mathrm{D}=\end{array}$ & $\begin{array}{l}\text { Corrected } \\
\text { based on } \\
\% \mathrm{D}=\end{array}$ & $\begin{array}{l}\text { Corrected } \\
\text { based on } \\
\% \mathrm{D}=\end{array}$ & $\begin{array}{l}\text { Corrected } \\
\text { based on } \\
\% \mathrm{D}_{2} \mathrm{O}\end{array}$ & $\begin{array}{l}\text { Corrected } \\
\text { based on } \\
\% \mathrm{D}_{2} \mathrm{O}\end{array}$ \\
\hline $\begin{array}{l}\text { Number of } \\
\text { peptides }\end{array}$ & 22 & 29 & 27 & 27 & 35 & 39 & 25 \\
\hline $\begin{array}{l}\text { Sequence } \\
\text { coverage }\end{array}$ & 96.6 & 96.4 & 94.3 & 69.4 & 96.3 & 88.3 & 85.5 \\
\hline $\begin{array}{l}\text { Average } \\
\text { peptide } \\
\text { /redundanc } \\
\text { y }\end{array}$ & $\begin{array}{l}\text { Length }=14.5 \\
\text { Redundancy }=2 \text {. } \\
2\end{array}$ & $\begin{array}{l}\text { Length }=13.4 \\
\text { Redundancy }=2 \text {. } \\
8\end{array}$ & $\begin{array}{l}\text { Length }=13 . \\
6 \\
\text { Redundanc } \\
y=2.6\end{array}$ & $\begin{array}{l}\text { Length }=12 \\
\text { Redundanc } \\
y=2.1\end{array}$ & $\begin{array}{l}\text { Length }=12 . \\
5 \\
\text { Redundanc } \\
\mathrm{y}=2.0\end{array}$ & $\begin{array}{l}\text { Length }=13 . \\
5 \\
\text { Redundanc } \\
y=2.8\end{array}$ & $\begin{array}{l}\text { Length }=12 . \\
1 \\
\text { Redundanc } \\
y=1.8\end{array}$ \\
\hline Replicates & 3 & 3 & 3 & 3 & 3 & 3 & 3 \\
\hline $\begin{array}{l}\text { Repeatabili } \\
\text { ty }\end{array}$ & $\begin{array}{l}\text { Average } \\
\text { StDev }=0.6 \%\end{array}$ & $\begin{array}{l}\text { Average } \\
\text { StDev }=0.6 \%\end{array}$ & $\begin{array}{l}\text { Average } \\
\text { StDev }=0.9 \\
\%\end{array}$ & $\begin{array}{l}\text { Average } \\
\text { StDev=0.8 } \\
\%\end{array}$ & $\begin{array}{l}\text { Average } \\
\text { StDev=0.7 } \\
\%\end{array}$ & $\begin{array}{l}\text { Average } \\
\text { StDev=0.8 } \\
\%\end{array}$ & $\begin{array}{l}\text { Average } \\
\text { StDev=0.7 } \\
\%\end{array}$ \\
\hline $\begin{array}{l}\text { Significant } \\
\text { differences } \\
\text { in HDX }\end{array}$ & $\begin{array}{l}>5 \% \text { and }>0.5 \\
\text { Da and } \\
\text { unpaired t-test } \\
\leq 0.01\end{array}$ & $\begin{array}{l}>5 \% \text { and }>0.5 \\
\text { Da and } \\
\text { unpaired t-test } \\
\leq 0.01\end{array}$ & $\begin{array}{l}>5 \% \text { and } \\
>0.5 \mathrm{Da} \text { and } \\
\text { unpaired t- } \\
\text { test } \leq 0.01\end{array}$ & $\begin{array}{l}>5 \% \text { and } \\
>0.5 \mathrm{Da} \text { and } \\
\text { unpaired } \mathrm{t}- \\
\text { test } \leq 0.01\end{array}$ & $\begin{array}{l}>5 \% \text { and } \\
>0.5 \mathrm{Da} \text { and } \\
\text { unpaired t- } \\
\text { test } \leq 0.01\end{array}$ & $\begin{array}{l}>5 \% \text { and } \\
>0.5 \mathrm{Da} \text { and } \\
\text { unpaired t- } \\
\text { test } \leq 0.01\end{array}$ & $\begin{array}{l}>5 \% \text { and } \\
>0.5 \mathrm{Da} \text { and } \\
\text { unpaired t- } \\
\text { test } \leq 0.01\end{array}$ \\
\hline
\end{tabular}


bioRxiv preprint doi: https://doi.org/10.1101/2021.06.01.446621; this version posted June 1, 2021. The copyright holder for this preprint (which was not certified by peer review) is the author/funder, who has granted bioRxiv a license to display the preprint in perpetuity. It is made available under aCC-BY-NC-ND 4.0 International license.

Supplemental Table 4. HDX Statistics for Figure 6 - Membrane

\begin{tabular}{|c|c|c|c|c|c|c|c|}
\hline Data set & TRAPP C1 & TRAPP C2 & TRAPP C2L & TRAPP C3 & TRAPP C4 & TRAPP C5 & TRAPP C6 \\
\hline $\begin{array}{l}\text { HDX } \\
\text { reaction } \\
\text { details }\end{array}$ & $\begin{array}{l}\% \mathrm{D}_{2} \mathrm{O}=62 \% \\
\mathrm{pH}_{\text {suma }}=7.5 \\
\mathrm{Temp}=20^{\circ} \mathrm{C}\end{array}$ & $\begin{array}{l}\% \mathrm{D} \mathrm{O}=62 \% \\
\mathrm{pH} \\
\mathrm{Temp}=20^{\circ} \mathrm{C}=7.5\end{array}$ & $\begin{array}{l}\% \mathrm{D}, \mathrm{O}=62 \% \\
\mathrm{pH}_{\text {rous }}=7.5 \\
\mathrm{Temp}=20^{\circ} \mathrm{C}\end{array}$ & $\begin{array}{l}\% \mathrm{D}, \mathrm{O}=62 \% \\
\mathrm{pH}_{\text {rous }}=7.5 \\
\mathrm{Temp}=20^{\circ} \mathrm{C}\end{array}$ & $\begin{array}{l}\% \mathrm{D} O=62 \% \\
\mathrm{pH}_{\text {sem }}=7.5 \\
\mathrm{Temp}=20^{\circ} \mathrm{C}\end{array}$ & $\begin{array}{l}\% \mathrm{D}_{2} \mathrm{O}=62 \% \\
\mathrm{pH}_{\text {rem }}=7.5 \\
\mathrm{Temp}=20^{\circ} \mathrm{C}\end{array}$ & $\begin{array}{l}\% \mathrm{D}_{2} \mathrm{O}=62 \% \\
\mathrm{pH}_{\mathrm{sum}}=7.5 \\
\mathrm{Temp}=20^{\circ} \mathrm{C}\end{array}$ \\
\hline $\begin{array}{l}\text { HDX time } \\
\text { course (s) }\end{array}$ & $\begin{array}{l}3,100,3000 \text { at } \\
20^{\circ} \mathrm{C}\end{array}$ & $\begin{array}{l}3,100,3000 \text { at } \\
20^{\circ} \mathrm{C}\end{array}$ & $\begin{array}{l}3,100, \\
3000 \text { at } \\
20^{\circ} \mathrm{C}\end{array}$ & $\begin{array}{l}3,100,3000 \text { at } \\
20^{\circ} \mathrm{C}\end{array}$ & $\begin{array}{l}3,100, \\
3000 \text { at } \\
20^{\circ} \mathrm{C}\end{array}$ & $\begin{array}{l}3,100, \\
3000 \text { at } \\
20^{\circ} \mathrm{C}\end{array}$ & $\begin{array}{l}3,100, \\
3000 \text { at } \\
20^{\circ} \mathrm{C}\end{array}$ \\
\hline $\begin{array}{l}\text { HDX } \\
\text { controls }\end{array}$ & $\mathrm{N} / \mathrm{A}$ & $\mathrm{N} / \mathrm{A}$ & $\mathrm{N} / \mathrm{A}$ & $\mathrm{N} / \mathrm{A}$ & $\mathrm{N} / \mathrm{A}$ & $\mathrm{N} / \mathrm{A}$ & $\mathrm{N} / \mathrm{A}$ \\
\hline $\begin{array}{l}\text { Back- } \\
\text { exchange }\end{array}$ & $\begin{array}{l}\text { Corrected } \\
\text { based on } \\
\% \mathrm{D}_{2} \mathrm{O}\end{array}$ & $\begin{array}{l}\text { Corrected } \\
\text { based on } \\
\% \mathrm{D} \text { O }\end{array}$ & $\begin{array}{l}\text { Corrected } \\
\text { based on } \\
\% D O\end{array}$ & $\begin{array}{l}\text { Corrected } \\
\text { based on \%D:O }\end{array}$ & $\begin{array}{l}\text { Corrected } \\
\text { based on } \\
\% D O\end{array}$ & $\begin{array}{l}\text { Corrected } \\
\text { based on } \\
\% D_{2} \mathrm{O}\end{array}$ & $\begin{array}{l}\text { Corrected } \\
\text { based on } \\
\% \mathrm{DO}\end{array}$ \\
\hline $\begin{array}{l}\text { Number of } \\
\text { peptides }\end{array}$ & 16 & 26 & 21 & 16 & 29 & 26 & 19 \\
\hline $\begin{array}{l}\text { Sequence } \\
\text { coverage }\end{array}$ & 84.1 & 88.6 & 86.4 & 60.0 & 91.3 & 82.4 & 87.9 \\
\hline $\begin{array}{l}\text { Average } \\
\text { peptide } \\
\text { /redundan } \\
\text { cy }\end{array}$ & $\begin{array}{l}\text { Length }=11.5 \\
\text { Redundancy= } \\
1.3\end{array}$ & $\begin{array}{l}\text { Length }=12.8 \\
\text { Redundancy= } \\
2.4\end{array}$ & $\begin{array}{l}\text { Length }= \\
12.3 \\
\text { Redundanc } \\
\mathrm{y}=1.8\end{array}$ & $\begin{array}{l}\text { Length }=12 \\
\text { Redundancy= } \\
1.1\end{array}$ & $\begin{array}{l}\text { Length }=12 . \\
9 \\
\text { Redundanc } \\
y=1.7\end{array}$ & $\begin{array}{l}\text { Length }=13 . \\
8 \\
\text { Redundanc } \\
y=1.9\end{array}$ & $\begin{array}{l}\text { Length=10. } \\
7 \\
\text { Redundanc } \\
\mathrm{y}=1.2\end{array}$ \\
\hline Replicates & 3 & 3 & 3 & 3 & 3 & 3 & 3 \\
\hline $\begin{array}{l}\text { Repeatabili } \\
\text { ty }\end{array}$ & $\begin{array}{l}\text { Average } \\
\text { StDev }=0.7 \%\end{array}$ & $\begin{array}{l}\text { Average } \\
\text { StDev }=0.6 \%\end{array}$ & $\begin{array}{l}\text { Average } \\
\text { StDev=0.9 } \\
\%\end{array}$ & $\begin{array}{l}\text { Average } \\
\text { StDev }=0.6 \%\end{array}$ & $\begin{array}{l}\text { Average } \\
\text { StDev=0.8 } \\
\%\end{array}$ & $\begin{array}{l}\text { Average } \\
\text { StDev }=0.9 \\
\%\end{array}$ & $\begin{array}{l}\text { Average } \\
\text { StDev }=1 \%\end{array}$ \\
\hline $\begin{array}{l}\text { Significant } \\
\text { differences } \\
\text { in HDX }\end{array}$ & $\begin{array}{l}>5 \% \text { and }>0.5 \\
\text { Da and } \\
\text { unpaired t-test } \\
\leq 0.01\end{array}$ & $\begin{array}{l}>5 \% \text { and }>0.5 \\
\text { Da and } \\
\text { unpaired t-test } \\
\leq 0.01\end{array}$ & $\begin{array}{l}>5 \% \text { and } \\
>0.5 \mathrm{Da} \text { and } \\
\text { unpaired t- } \\
\text { test } \leq 0.01\end{array}$ & $\begin{array}{l}>5 \% \text { and }>0.5 \\
\text { Da and } \\
\text { unpaired t-test } \\
\leq 0.01\end{array}$ & $\begin{array}{l}>5 \% \text { and } \\
>0.5 \mathrm{Da} \text { and } \\
\text { unpaired } \mathrm{t}- \\
\text { test } \leq 0.01\end{array}$ & $\begin{array}{l}>5 \% \text { and } \\
>0.5 \mathrm{Da} \text { and } \\
\text { unpaired t- } \\
\text { test } \leq 0.01\end{array}$ & $\begin{array}{l}>5 \% \text { and } \\
>0.5 \mathrm{Da} \text { and } \\
\text { unpaired } \mathrm{t}- \\
\text { test } \leq 0.01\end{array}$ \\
\hline Data set & TRAPP C8 & TRAPP C9 & TRAPP C10 & TRAPP C11 & TRAPP C12 & TRAPP C13 & \\
\hline $\begin{array}{l}\text { HDX } \\
\text { reaction } \\
\text { details }\end{array}$ & $\begin{array}{l}\% \mathrm{DO}=62 \% \\
\mathrm{pH}_{\text {sous }}=7.5 \\
\mathrm{Temp}=20^{\circ} \mathrm{C}\end{array}$ & $\begin{array}{l}\% \mathrm{D}_{2} \mathrm{O}=62 \% \\
\mathrm{pH}_{\text {max }}=7.5 \\
\mathrm{Temp}=20^{\circ} \mathrm{C}\end{array}$ & $\begin{array}{l}\% \mathrm{D} O=62 \% \\
\mathrm{pH}_{\text {raxs }}=7.5 \\
\mathrm{Temp}=20^{\circ} \mathrm{C}\end{array}$ & $\begin{array}{l}\% \mathrm{D}_{2} \mathrm{O}=62 \% \\
\mathrm{pH}_{\text {toan }}=7.5 \\
\mathrm{Temp}=20^{\circ} \mathrm{C}\end{array}$ & $\begin{array}{l}\% \mathrm{D} O=62 \% \\
\mathrm{pH}_{\text {roum }}=7.5 \\
\mathrm{Temp}=20^{\circ} \mathrm{C}\end{array}$ & $\begin{array}{l}\% \mathrm{D} \mathrm{O}=62 \% \\
\mathrm{pH}_{\text {meas }}=7.5 \\
\mathrm{Temp}=20^{\circ} \mathrm{C}\end{array}$ & \\
\hline $\begin{array}{l}\text { HDX time } \\
\text { course } \\
\text { (seconds) }\end{array}$ & $\begin{array}{l}3,100,3000 \text { at } \\
20^{\circ} \mathrm{C}\end{array}$ & $\begin{array}{l}3,100,3000 \text { at } \\
20^{\circ} \mathrm{C}\end{array}$ & $\begin{array}{l}3,100, \\
3000 \text { at } \\
20^{\circ} \mathrm{C}\end{array}$ & $\begin{array}{l}3,100,3000 \text { at } \\
20^{\circ} \mathrm{C}\end{array}$ & $\begin{array}{l}3,100, \\
3000 \text { at } \\
20^{\circ} \mathrm{C}\end{array}$ & $\begin{array}{l}3,100, \\
3000 \text { at } \\
20^{\circ} \mathrm{C}\end{array}$ & \\
\hline $\begin{array}{l}\text { HDX } \\
\text { controls }\end{array}$ & $\mathrm{N} / \mathrm{A}$ & $\mathrm{N} / \mathrm{A}$ & $\mathrm{N} / \mathrm{A}$ & N/A & $\mathrm{N} / \mathrm{A}$ & $\mathrm{N} / \mathrm{A}$ & \\
\hline $\begin{array}{l}\text { Back- } \\
\text { exchange }\end{array}$ & $\begin{array}{l}\text { Corrected } \\
\text { based on } \\
\% \mathrm{D}_{2} \mathrm{O}\end{array}$ & $\begin{array}{l}\text { Corrected } \\
\text { based on } \\
\% D O\end{array}$ & $\begin{array}{l}\text { Corrected } \\
\text { based on } \\
\% D O\end{array}$ & $\begin{array}{l}\text { Corrected } \\
\text { based on } \% D_{2} \mathrm{O}\end{array}$ & $\begin{array}{l}\text { Corrected } \\
\text { based on } \\
\% D O\end{array}$ & $\begin{array}{l}\text { Corrected } \\
\text { based on } \\
\% \mathrm{DO}\end{array}$ & \\
\hline $\begin{array}{l}\text { Number of } \\
\text { peptides }\end{array}$ & 142 & 192 & 190 & 132 & 62 & 49 & \\
\hline $\begin{array}{l}\text { Sequence } \\
\text { coverage }\end{array}$ & 82.3 & 95.9 & 85 & 87.3 & 89.1 & 78.2 & \\
\hline $\begin{array}{l}\text { Average } \\
\text { peptide } \\
\text { /redundan } \\
\text { cy }\end{array}$ & $\begin{array}{l}\text { Length }=15 \\
\text { Redundancy= } \\
1.5\end{array}$ & $\begin{array}{l}\text { Length }=13 \\
\text { Redundancy= } \\
2.2\end{array}$ & $\begin{array}{l}\text { Length }=13 . \\
6 \\
\text { Redundanc } \\
y=2.0\end{array}$ & $\begin{array}{l}\text { Length }=12 \\
\text { Redundancy= } \\
1.4\end{array}$ & $\begin{array}{l}\text { Length }=14 . \\
4 \\
\text { Redundanc } \\
y=2.0\end{array}$ & $\begin{array}{l}\text { Length }=10 . \\
8 \\
\text { Redundanc } \\
y=1.3\end{array}$ & \\
\hline Replicates & 3 & 3 & 3 & 3 & 3 & 3 & \\
\hline $\begin{array}{l}\text { Repeatabili } \\
\text { ty }\end{array}$ & $\begin{array}{l}\text { Average } \\
\text { StDev=1\% }\end{array}$ & $\begin{array}{l}\text { Average } \\
\text { StDev }=0.9 \%\end{array}$ & $\begin{array}{l}\text { Average } \\
\text { StDev=0.8 } \\
\%\end{array}$ & $\begin{array}{l}\text { Average } \\
\text { StDev }=0.9 \%\end{array}$ & $\begin{array}{l}\text { Average } \\
\text { StDev }=0.8 \\
\%\end{array}$ & $\begin{array}{l}\text { Average } \\
\text { StDev=1\% }\end{array}$ & \\
\hline $\begin{array}{l}\text { Significant } \\
\text { differences } \\
\text { in HDX }\end{array}$ & $\begin{array}{l}>5 \% \text { and }>0.5 \\
\text { Da and } \\
\text { unpaired t-test } \\
\leq 0.01\end{array}$ & $\begin{array}{l}>5 \% \text { and }>0.5 \\
\text { Da and } \\
\text { unpaired t-test } \\
\leq 0.01\end{array}$ & $\begin{array}{l}>5 \% \text { and } \\
>0.5 \mathrm{Da} \text { and } \\
\text { unpaired t- } \\
\text { test } \leq 0.01\end{array}$ & $\begin{array}{l}>5 \% \text { and }>0.5 \\
\text { Da and } \\
\text { unpaired t-test } \\
\leq 0.01\end{array}$ & $\begin{array}{l}>5 \% \text { and } \\
>0.5 \mathrm{Da} \text { and } \\
\text { unpaired t- } \\
\text { test } \leq 0.01\end{array}$ & $\begin{array}{l}>5 \% \text { and } \\
>0.5 \mathrm{Da} \text { and } \\
\text { unpaired t- } \\
\text { test } \leq 0.01\end{array}$ & \\
\hline
\end{tabular}




\section{References}

[1] X. Robert, P. Gouet, Deciphering key features in protein structures with the new ENDscript server, Nucleic Acids Res. 42 (2014) W320-324.

https://doi.org/10.1093/nar/gku316.

[2] M.L. Jenkins, N.J. Harris, U. Dalwadi, K.D. Fleming, D.S. Ziemianowicz, A. Rafiei, E.M. Martin, D.C. Schriemer, C.K. Yip, J.E. Burke, The substrate specificity of the human TRAPPII complex's Rab-guanine nucleotide exchange factor activity, Communications Biology. 3 (2020) 1-12. https://doi.org/10.1038/s42003-02001459-2. 